\title{
ejavecJOURNAL EAST JAVA ECONOMIC JOURNAL

\section{CATTLE FARMING 4.0 : DEVELOPMENT OF LIVESTOCK SECTOR THROUGH E-AGRIOVEST (DIGITAL BASED INVESTMENT) TO ACCELERATE ECONOMIC GROWTH IN EAST JAVA}

\author{
Julita Hasanah*1 \\ Dian Puspasari Ina Ayati² \\ Dimas Brillian Syaban Pramana ${ }^{3}$
}

\author{
${ }^{1}$ Fakultas Ekonomi dan Manajemen, Institut Pertanian Bogor \\ ${ }^{2}$ PT Perkebunan Nusantara XII \\ ${ }^{3}$ PT Bank Negara Indonesia
}

\begin{abstract}
Livestock is one of strategic sectors in supporting the East Java economy. Data recorded that 20.89\% (4.5 millions) of the national beef cattle population came from East Java. However, beef production was still relatively moderate $(23.17 \%)$ and had not been able to fulfill national beef consumption which continues to grow (4.66\%). It caused the price of local beef is much more expensive than imported beef. Study shown that the structure of East Java's livestock was still dominated by traditional farm system. The purpose of this study is to a) examine the performance of the livestock sector in East Java; b) analyze e-agriovest system as a solution to cattle farming problems; c) analyze the contribution of e-agriovest to the East Java economy. The research was conducted in Jember which is one of the centers of beef cattle farming in East Java. The first objective was analyzed using descriptive methods while the second and third objectives were analyzed using systems analysis and econometric models with a simultaneous equation system using the Two Stage Least Square (2SLS) method. The results showed the characteristics of traditional farms, including the number of small cattle (1-3 cows) (56.67\%), unregular sales period (60\%), forage feed (100\%), saving function (46.66\%) and sales system through blantik/traditional broker (66.67\%). The results showed that e-agriovest was simulated to increase beef production by up to $20 \%$ by integrating the livestock sector from upstream to downstream. The $20 \%$ increase in production is projected to upgrade the beef cattle population by $8.64 \%$. The increase in beef production will consequences beef consumption (1.13\%). Then, it will decrease beef prices (0.15\%). Result shows that e-agriovest system is projected to increase East Java's GRDP (2.83\%). Not only in economic sector, result showed that implementation of e-agriovest system can improve East Java's livestock sector socially and environmentally.
\end{abstract}

Keywords: Economic Growth, Investment, Cattle Farming

JEL : 04,E2,Q1

\section{ABSTRAK}

Peternakan merupakan salah satu subsektor strategis dalam mendukung perekonomian Jawa Timur. Data mencatat sebesar 20,89\% (4,5 juta ekor) populasi sapi potong nasional berasal dari Jawa Timur. Kendati begitu, produksi daging sapi masih tergolong sedang $(23,17 \%)$ dan belum mampu memenuhi konsumsi daging nasional yang terus mengalami pertumbuhan (4.66\%) sehingga harga daging sapi lokal jauh lebih mahal dibandingkan dengan harga daging impor. Berdasarkan riset terdahulu, hal ini disebabkan struktur peternakan Jawa Timur yang masih didomina-

East Java Economic Journal, p-ISSN: 2597-8780 DOI: 10.53572/ejavec.v3i1.25, Open access undera Creative Commons Attribution- 4.0 
si oleh peternakan rakyat. Permasalahan mendasar isu daging sapi tersebut perlu segera diselesaikan dengan melibatkan peran teknologi digital. Tujuan penelitian ini untuk a) mengkaji keragaan subsektor peternakan di Jawa timur; b) menganalisis sistem e-agriovest sebagai solusi permasalahan peternakan; c) menganalisis kontribusi e-agriovest terhadap perekonomian Jawa Timur. Penelitian dilakukan di Kabupaten Jember yang merupakan salah satu sentra peternakan sapi potong di Jawa Timur. Tujuan pertama dianalisis dengan menggunakan metode deskriptif sementara tujuan kedua dan ketiga dianalisis menggunakan analisis sistem dan model ekonometrika dengan sistem persamaan simultan melalui metode Two Stage Least Square (2SLS). Hasil penelitian menunjukkan karakteristik peternakan rakyat antara lain jumlah ternak kecil (1-3 ekor) (56,67\%), periode penjualan sesuai kebutuhan (60\%), masih menggunakan pakan hijauan (100\%), fungsi ternak saving (46,66\%) dan sistem penjualan melalui blantik (66,67\%). Hasil penelitian menunjukkan e-agriovest disimulasikan dapat meningkatkan produksi daging sapi hingga $20 \%$ dengan mengintegrasikan sektor peternakan dari hulu ke hilir. Peningkatan produksi sebesar 20\% tersebut diproyeksikan dapat meningkatkan populasi ternak sapi potong sebesar $8,64 \%$. Peningkatan produksi daging sapi potong juga akan memiliki konsekuensi tumbuhnya konsumsi daging sapi (1,13\%). Dampak yang terjadi dari peningkatan produksi sapi potong juga akan menyebabkan penurunan harga daging sapi sebesar 0,15\%. Berdasarkan hasil analisis, sistem e-agriovest diproyeksikan meningkatkan PDRB Jawa Timur (2,83\%). Tak hanya itu, sistem e-agriovest menjadi salah satu langkah implementatif dalam pengembangan sektor peternakan dari aspek sosial dan lingkungan.

Kata Kunci: Investasi, Pertumbuhan Ekonomi, Sektor Peternakan

JEL : 04,E2,Q1

\section{Pendahuluan}

Suhariyono (2013) menyatakan bahwa pertumbuhan ekonomi merupakan sebuah strategi yang sering digunakan beberapa negara dalam melaksanakan pembangunan ekonomi. Perekonomian suatu daerah dapat dilihat dari kontribusi PDRB terhadap PDB Nasional. Pada tahun 2017 perekonomian Jawa Timur merupakan salah satu perekonomian terbesar di Indonesia setelah DKI Jakarta, dengan kontribusi sebesar 14,61\% terhadap PDB Nasional (Bank Indonesia, 2018). Sebagai salah satu penyumbang PDB Nasional terbesar, perekonomian Jawa Timur bertumpu pada sektor pertanian. Sektor pertanian diketahui merupakan salah satu sektor utama yang mendukung peningkatan pertumbuhan ekonomi Jawa Timur dengan nilai sebesar 13\% (BPS Jawa Timur, 2017).

Salah satu subsektor pertanian unggulan Jawa Timur adalah subsektor peternakan. Subsektor peternakan memiliki peranan penting dalam perekonomian Jawa Timur dilihat dari kontribusi subsektor peternakan $(20,24 \%)$ terhadap sektor pertanian Jawa Timur (Hudang, 2016). Terlepas dari kontribusinya yang tinggi, fakta menunjukkan bahwa subsektor peternakan masih rentan terhadap goncangan ekonomi (shock). Perekonomian nasional secara agregat mengalami kontraksi yang luar biasa hebat (13.13\%) pada tahun 1998. Sementara itu, sektor pertanian hanya mengalami kontraksi sebesar $1.33 \%$, namun salah satu subsektor pertanian yang mengalami kontraksi yang cukup besar adalah peternakan $( \pm 13.94 \%)$. Hal ini disebabkan komponen impor yang cukup besar dalam struktur input subsektor peternakan (Kusriatmi, 2014).

Peternakan Jawa Timur menyumbangkan sekitar 4,5 juta ekor sapi atau sebesar 20,89\% dari kebutuhan sapi potong nasional pada tahun 2017 (BPS Jawa Timur, 2018). Dibalik peranannya yang sangat besar, Jawa Timur masih menghadapi persoalan mengenai pola peternakan yang sebagian besar didominasi oleh peternakan rakyat. Menurut Zainuddin (2015), lebih dari $90 \%$ peternak sapi potong di Indonesia adalah peternak rakyat dengan karakteristik: (a) skala usaha relatif kecil (b) merupakan usaha rumah tangga (c) cara memeliharanya masih tradisional; dan d) seringkali ternak digunakan sebagai sumber tenaga kerja. Karakter- 
Hasanah, J., Ayati, D. Cattle Farming 4.0 : Development of Livestock Sector Through E-Agriovest (Digital

P. I, \& Pramana, D. B. S $\quad$ Based Investment) to Accelerate Economic Growth in East Java

istik tersebut menjadi salah satu penyebab produksi daging sapi Jawa Timur masih tergolong rendah $(23,17 \%)$ karena peternak akan menjual ternaknya ketika memerlukan uang tunai. Sehingga fluktuasi dan gejolak harga ternak biasanya terjadi bersamaan dengan gejolak kebutuhan sosial masyarakat, terutama pada hari-hari besar keagamaan. Harga daging sapi ritel di Indonesia bisa mencapai angka Rp. 115.779,00,- sementara harga daging sapi ritel sekelas di Australia hanya sekitar Rp. 50.000,00,-(BPS Jawa Timur, 2018). Banyak pengamat yang mengatakan bahwa harga daging sapi di Indonesia adalah yang paling mahal di dunia. Oleh karena itu, sangat penting membahas mengenai karakteristik dan keragaan subsektor peternakan Jawa Timur sebagai referensi kebijakan dalam peningkatan produksi daging sapi.

Penyelesaian dari permasalahan masih rendahnya produksi daging sapi banyak dilakukan melalui kebijakan-kebijakan yang sifatnya jangka pendek seperti kebijakan impor dan operasi pasar saat hari-hari besar keagamaan. Penyelesaian permasalahan subsektor peternakan pada era digital 4.0 saat ini perlu melibatkan peran teknologi contohnya dengan implementasi e-commerce. Saat ini hampir semua sektor mengusung revolusi industri 4.0 (industri digital). Implementasi Industri 4.0 tersebut bertujuan untuk menciptakan pertumbuhan ekonomi yang lebih berkelanjutan yang salah satunya dapat diterapkan pada subsektor peternakan sapi potong Jawa Timur (Satya, 2018).

Pengembangan subsektor peternakan berbasis e-commerce masih terkendala dengan kondisi pelaku subsektor peternakan/peternak belum bisa menguasai teknologi digital. Selain itu, keadaan infrastruktur di daerah pertanian masih belum menunjang untuk pelaksanaan e-commerce pada subsektor peternakan. Dari permasalahan tersebut diperlukan adanya solusi berupa kelembagaan pertanian yang berfungsi sebagai "fasilitator" guna membantu pelaku subsektor peternakan dalam mengakses teknologi digital. Selain itu, pentingnya kelembagaan petani diakui dalam pembangunan pertanian baik di negara industri maupun negara sedang berkembang seperti Indonesia. Kelembagaan petani diharapkan mampu membantu petani keluar dari persoalan kesenjangan ekonomi petani (Anantanyu, 2011).

e-agriovest atau e-commerce Agriculture Livestock Investment merupakan model kelembagaan sebagai strategi implementatif guna mempercepat pertumbuhan ekonomi Jawa Timur melalui peningkatan produksi daging sapi dengan melibatkan teknologi digital. Hal tersebut mendasari penelitian untuk menyusun model $e$-agriovest yang diharapkan sebagai solusi permasalahan sektor peternakan Jawa Timur berbasis kelembagaan dan investasi yang melibatkan teknologi digital. Adanya e-agriovest diharapkan mampu meningkatkan produksi daging sapi melalui pengembangan sektor peternakan berbasis wilayah potensial ternak Jawa Timur dengan mengintegrasikan industri pakan, pembibitan, budidaya ternak dan Rumah Potong Hewan. Implikasi adanya e-agriovest dapat meningkatkan produksi daging sapi potong Jawa sehingga akan secara berkelanjutan mempercepat pertumbuhan ekonomi Jawa Timur. Oleh karena itu, sangat penting untuk meneliti dampak adanya e-agriovest terhadap pertumbuhan ekonomi Jawa Timur.

Berdasarkan latar belakang di atas, penelitian ini bertujuan untuk menganalisis karakteristik dan keragaan subsektor peternakan melalui kontribusi terhadap PDRB Jawa Timur, model sistem e-agriovest, dan dampak adanya sistem e-agriovest terhadap pertumbuhan ekonomi Jawa Timur. Penelitian ini diharapkan mampu memberikan kontribusi kepada para pengambil kebijakan dalam memberikan informasi mengenai strategi akselerasi pertumbuhan ekonomi Jawa Timur melalui subsektor peternakan. Bagian kedua dari paper ini mengulas teori dan studi literatur, sementara bagian ketiga mengulas metodologi dan data yang digunakan. Bagian keempat menyajikan hasil estimasi dan analisisnya sementara kesimpulan dan saran disajikan pada bagian terakhir.

\section{Telaah Literatur}

Sapi merupakan salah satu komoditas peternakan yang penting di Indonesia, namun dalam beberapa dekade harga daging sapi cenderung mengalami kenaikan harga dibandingkan komoditas peternakan lainnya. Fluktuasi harga sering terjadi pada daging sapi, padahal 
daging merupakan sumber protein hewani yang banyak dibutuhkan oleh masyarakat. Hingga saat ini Indonesia belum dapat memenuhi kebutuhan daging, sehingga alternatif yang digunakan saat ini adalah impor daging. Tingginya kebutuhan daging di Indonesia juga tidak bisa terlepas oleh pertumbuhan penduduk yang dalam dekade ini mengalami peningkatan. Menurut Yusdja dan Ilham (2004) kekurangan suplai daging sapi yang tidak seimbang akan menimbulkan ketidakstabilan pada perekonomian nasional. Salah satu provinsi yang mensuplai daging sapi tertinggi di Indonesia adalah Provinsi Jawa Timur, dengan rata-rata kontribusi komoditas sapi dalam kurun waktu lima tahun terakhir mencapai 99.880 ton atau sebesar $19.51 \%$ produksi daging nasional.

Fluktuasi produksi dan harga daging sapi memiliki konsekuensi terhadap PDRB Provinsi Jawa Timur. Menurut BPS Jawa Timur (2018) kontribusi subsektor peternakan di Provinsi Jawa Timur juga tercatat mengalami peningkatan. Subsektor peternakan menyumbang PDRB Provinsi Jawa Timur mencapai $2.07 \%$, dimana angka tersebut selalu mengalami fluktuasi yang cenderung meningkat dalam dekade terakhir. Kenaikan angka PDRB tersebut disebabkan karena kenaikan produksi daging sejalan dengan program swasembada daging pada tahun 2014. Pengembangan program tersebut sudah berjalan dengan baik, akan tetapi pertumbuhan sektor peternakan belum dapat dicapai sepenuhnya.

Menurut Suwandi (2015) pertumbuhan ekonomi dapat dikatakan sebagai suatu kenaikan kapasitas dalam jangka panjang pada suatu negara yang bersangkutan untuk menyediakan berbagai keperluan barang ekonomi pada penduduknya. Terdapat tiga faktor komponen utama dalam pertumbuhan ekonomi suatu negara. Ketiga komponen tersebut antara lain: a) akumulasi modal, meliputi semua bentuk atau jenis investasi baru yang ditanamkan pada tanah, peralatan fisik, dan modal atau sumberdaya manusia yang ada; b) pertumbuhan penduduk, yang pada akhirnya akan memperbanyak jumlah angkatan kerja sehingga diharapkan akan meningkatkan produksi di berbagai sector; dan c) kemajuan teknologi, meliputi berbagai cara baru atau perbaikan cara lama dalam menangani suatu pekerjaan tertentu.

Ketiga komponen tersebut sangat berkaitan erat dengan distribusi pendapatan masyarakat. Distribusi pendapatan yang baik adalah adanya pemerataan, hal ini juga harus diimbangi dengan pertumbuhan ekonomi agar meminimalisir pemerataan kemiskinan. Setidaknya masih terdapat dua syarat mutlak agar ketimpangan tidak terjadi, syarat tersebut yaitu dengan memperluas kesempatan kerja dan meningkatkan produktivitas. Kesempatan kerja yang semakin meluas maka akan berdampak pada peningkatan kesempatan kerja masyarakat serta peningkatan pendapatan masyarakat (Kuncoro, 2004).

Menurut Lin dan Liu (2000) pertumbuhan ekonomi semakin lebih mudah terwujud apabila investasi modal semakin ditingkatkan pada berbagai sektor yang ada, di lain sisi dengan melakukan efisiensi terhadap sumberdaya yang dimiliki agar produktivitas dari sumberdaya yang ada dapat tersalurkan dengan maksimal. Pernyataan tersebut menunjukkan bahwa desentralisasi fiskal mempunyai peranan yang sangat penting dalam pertumbuhan ekonomi dalam suatu daerah. Desentralisasi fiskal juga akan mampu meningkatkan pertumbuhan ekonomi dan kesejahteraan masyarakat. Hal tersebut dikarenakan pemerintah daerah akan lebih efisien dalam proses produksi dan penyediaan barang-barang publik dengan adanya otonomi daerah yang diberikan oleh pusat. Pertumbuhan ekonomi dapat dicapai dengan melakukan beberapa pendekatan, salah satunya adalah dengan keberadaan kelembagaan.

Menurut Siregar dan Ilham (2016) kelembagaan usaha peternakan merupakan aspek yang sangat penting dalam usaha ternak meskipun tidak berkaitan langsung terhadap produksi ternak, namun berpengaruh terhadap efisiensi usaha ternak yang dilakukan. Kelembagaan usaha peternakan umumnya berisikan para peternak yang memiliki komoditas ternak yang sejenis. Partisipan dalam kelembagaan peternakan memiliki tujuan yang sama yakni meningkatkan produksi mereka, dengan meningkatnya produksi ternak yang diusahakan maka secara tidak langsung pendapatan dan kesejahteraan mereka akan meningkat pula.

Pada negara maju seperti Amerika Serikat misalnya peran kelembagaan sangat pent- 
Hasanah, J., Ayati, D. Cattle Farming 4.0 : Development of Livestock Sector Through E-Agriovest (Digital

P. I, \& Pramana, D. B. S $\quad$ Based Investment) to Accelerate Economic Growth in East Java

ing dalam peningkatan perekonomian masyarakatnya. Menurut Paulson et al. (2010) kelembagaan yang ada di Amerika Serikat umumnya berupa kemitraan. Jumlah perorangan yang tergabung dalam model kelembagaan tersebut terus meningkat hingga $41 \%$ dalam beberapa dekade terakhir. Kelembagaan yang menyediakan kemitraan umumnya lebih banyak menyediakan kepastian, meliputi kepastian pemasaran, distribusi, dan produksi. Meningkatnya minat individu untuk mengembangkan usahanya tersebut tentu secara tidak langsung juga akan berpengaruh pada peningkatan perekonomian nasional.

\section{Metode Penelitian}

Penentuan daerah atau lokasi penelitian ini dilakukan secara sengaja (purposive methods). Lokasi penelitian yang dipilih adalah Provinsi Jawa Timur dengan pertimbangan Jawa Timur memiliki kontribusi PDB Nasional tertinggi kedua. Selain itu, Jawa Timur memiliki kontribusi subsektor peternakan tertinggi di Indonesia. Lima daerah sentra dengan populasi sapi potong tertinggi di Jawa Timur antara lain Sumenep, Tuban, Probolinggo, Jember, dan Malang dimana sebagai percontohan penelitian dilakukan di Kabupaten Jember.

Metode pengambilan contoh dalam penelitian ini dengan menggunakan metode multistage random sampling. Menurut Gulo (2004), penarikan sampel dengan cara ini biasanya dilakukan pada populasi yang anggotanya tersebar pada wilayah yang luas, misalnya skala provinsi atau kabupaten. Tahap pertama yang dilakukan adalah pemilihan kabupaten sampel secara purposive yaitu Kabupaten Jember. Hal ini dikarenakan Kabupaten Jember merupakan daerah yang memiliki populasi sapi potong terbesar kedua setelah Kabupaten Sumenep dengan jumlah populasi sebesar 324.230 ekor. Tahap kedua adalah memilih secara purposive kecamatan sampel yaitu Kecamatan Sumberjambe yang merupakan kecamatan dengan populasi sapi potong terbesar di Kabupaten Jember. Tahap ketiga adalah pemilihan desa sampel secara purposive yaitu Desa Jambearum yang memiliki populasi sapi tertinggi di Kecamatan Sumberjambe. Tahap keempat adalah pemilihan sampel peternak secara purposive. Peneliti memilih sebanyak 30 peternak rakyat. Peternak yang dipilih sebagai sampel merupakan peternak rakyat (yang memiliki 1-4 ekor sapi) dengan status kepemilikan sendiri (bukan gaduh yaitu sistem bagi hasil antara pemilik sapi dengan pemelihara). Adapun pengambilan sampel secara multistage random sampling dapat dilihat pada Gambar 1 berikut.

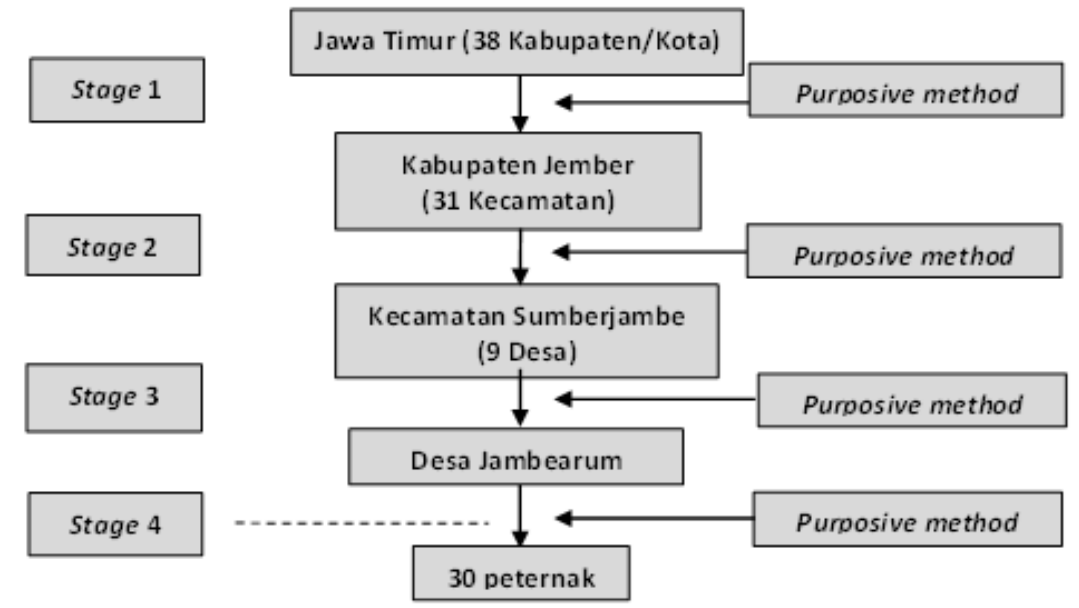

Gambar 1: Bagan Pengambilan Contoh dengan Metode Multistage Random Sampling

Sumber : Data Primer (diolah)

Metode penelitian yang digunakan dalam penelitian ini adalah metode deskriptif kuantitatif. Menurut Nazir (2009), tujuan dari penelitian deskriptif kuantitatif adalah untuk membuat deskripsi, gambaran atau lukisan secara sistematis, faktual dan akurat mengenai fakta-fakta, sifat-sifat serta hubungan antar fenomena yang diselidiki berdasarkan hasil anal- 
isis berupa angka-angka. Data yang digunakan adalah data sekunder time series tahunan selama periode 1997-2017 yang diperoleh dari berbagai sumber, diantaranya Badan Pusat Statistik (BPS), Kementan, Disperindag serta studi berbagai literatur terkait. Analisis mengenai perkembangan sektor peternakan Jawa Timur menggunakan analisis deskriptif. Metode analisis keragaan atau perkembangan subsektor peternakan sapi potong Jawa Timur dilakukan berdasarkan ketersediaan data series yang mencakup indikator populasi, produksi, konsumsi, harga serta ekspor dan impor di tingkat produsen maupun di tingkat konsumen dengan analisis deskriptif sederhana.

Analisis pembentukan model kelembagaan berbasis e-commerce yaitu e-agriovest dilakukan dengan menggunakan analisis sistem. Kondisi kelembagaan dianalisis dengan analisis interaktif yang meliputi reduksi data, sajian data, dan penarikan kesimpulan (Sutopo, 2006). Pembentukan model kelembagaan sebagai strategi peningkatan produksi daging sapi guna mencapai akselerasi pertumbuhan ekonomi Jawa Timur dianalisis dengan pendekatan sistem sebagai berikut, (a) analisis kebutuhan, yaitu interaksi antara respon yang tumbuh dari seseorang pengambil keputusan (desicion maker) terhadap jalannya sistem. Kebutuhan ini dapat meliputi hasil survei, pendapat ahli, hasil diskusi, dan sebagainya (Eriyatno, 1999); dan (b) persyaratan kebutuhan, yaitu dibutuhkan untuk kelangsungan identifikasi sistem. Setiap sistem mempunyai persyaratan kebutuhan yang berbeda-beda, dan karena itu tidak ada ketentuan yang sifatnya mutlak. Kebutuhan yang dianggap memenuhi syarat dalam analisis ini adalah dilihat kedekatannya dalam konteks pembentukan model kelembagaan; (c) Identifikasi sistem, yaitu rantai hubungan antara pernyataan kebutuhan-kebutuhan dengan pernyataan khusus dari masalah yang harus dipecahkan untuk melengkapi kebutuhan-kebutuhan tersebut (Eriyatno, 1999).

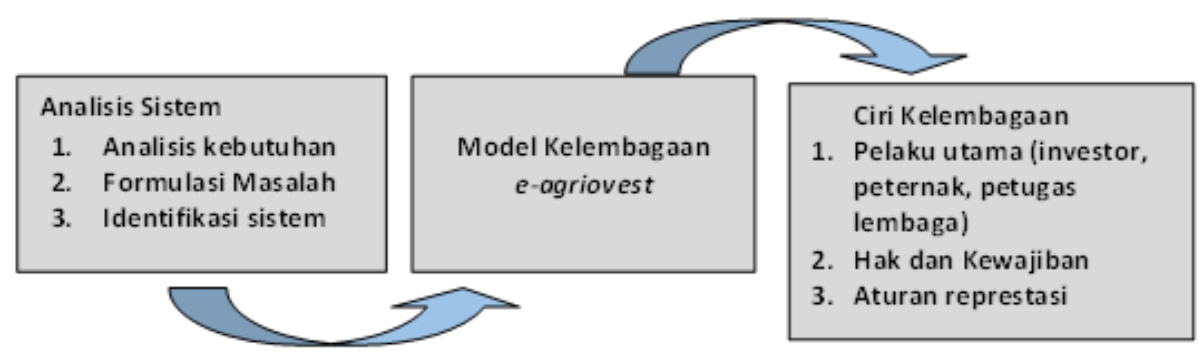

\section{Gambar 2: Metode Analisis Sistem \\ Sumber : Eriyatno (1999)}

Analisis mengenai dampak sistem e-agriovest terhadap PDRB Jawa Timur dilakukan menggunakan model ekonometrika dengan sistem persamaan simultan melalui metode Two Stage Least Square (2SLS) menggunakan alat bantu program Statistikal Analysis System (SAS) versi 9.1. Model terdiri dari persamaan struktural dan persamaan identitas yang dikelompokkan menjadi 6 blok persamaan, yaitu (1) blok produksi ternak sapi potong, (2) blok populasi ternak sapi potong, (3) blok permintaan daging sapi, (4) blok penawaran daging sapi, (5) blok harga daging sapi, (6) blok pertumbuhan PDRB Jawa Timur. Model persamaan ekonometrika dapat dijelaskan sebagai berikut.

1. Produksi daging sapi potong

$$
Q D S=\alpha_{0}+\alpha_{1} L L H D S+\alpha_{2} P O P T S P+\alpha_{3} G H D S M+U_{1}
$$

Tanda parameter dugaan yang diharapkan : $a_{1} a_{2}>0 ; a_{3}<0$

2. Populasi ternak sapi potong

$$
P O P T S P=b_{0}+b_{1} D S+b_{2} H D S M+b_{3} H D S+U_{2}
$$


Tanda parameter dugaan yang diharapkan $: b_{1}, b_{3}>0 ; b_{2}<0$

3. Permintaan daging sapi

$$
Q D D S=c_{0}+c_{1} H D S+c_{2} H D A Y+c_{3} Q D S+c_{4} Q P O P+U_{3}
$$

Tanda parameter dugaan yang diharapkan: $\mathrm{c}_{3}, \mathrm{C}_{4}>0 ; \mathrm{c}_{1}<0 ; 0<\mathrm{c}_{2}<0$

4. Harga riil daging sapi

$$
H D S=d_{0}+d_{1} H D S M+d_{2} Q D S+d_{3} L Q D D S+U_{4}
$$

Tanda parameter dugaan yang diharapkan : $d_{1}, d_{3}>0 ; d_{2}<0$

5. PDRB Jawa Timur

$$
P D R B J=e_{0}+e_{1} L Q D S+e_{2} P D R B P+e_{3} P O P T S P+U_{5}
$$

6. Tingkat pertumbuhan PDRB Jawa Timur (GPDRBJ) merupakan persamaan identitas berikut

$$
G P D R B J=\frac{(P D R B J-L P D R B J)}{L P D R B J} \times 100 \%
$$

Tanda parameter dugaan yang diharapkan : e1, e2, e3 $>0$

Tabel 1: Variabel Model Ekonometrika Pertumbuhan Ekonomi Jawa Timur

\begin{tabular}{lll}
\hline \multicolumn{1}{c}{ Variabel } & \multicolumn{1}{c}{ Simbol } & Satuan \\
\hline QDS & Jumlah produksi daging sapi & Ton \\
\hline LQDS & Lag Jumlah produksi daging sapi & $\mathrm{Rp} / \mathrm{Kg}$ \\
\hline HDS & Harga daging sapi & $\mathrm{Rp} / \mathrm{Kg}$ \\
\hline LLHDS & Harga daging sapi tahun t-2 & $\mathrm{Ekor}$ \\
\hline POPTSP & Populasi ternak sapi potong & $\mathrm{Kg}$ \\
\hline QDDS & Permintaan daging sapi & $\mathrm{Kg}$ \\
\hline LQDDS & Lag Permintaan daging sapi & $\mathrm{Rp} / \mathrm{Kg}$ \\
\hline HDAY & Harga riil daging ayam & $\mathrm{US \$} / \mathrm{Ton}$ \\
\hline HDSM & Harga rill daging sapi impor & $\mathrm{Rp} / \mathrm{Kg}$ \\
\hline GHDSM & Pertumbuhan Harga rill daging sapi impor & Jiwa (Orang) \\
\hline QPOP & Jumlah Penduduk Jawa Timur & $\mathrm{Rp} \mathrm{Juta}$ \\
\hline PDRBJ & PDRB Jawa Timur & $\mathrm{Rp} \mathrm{Juta}$ \\
\hline PDRBP & PDRB subsektor peternakan & $\%$ \\
\hline GPDRBJ & Pertumbuhan PDRB Jawa Timur & $\mathrm{Rp} \mathrm{Juta}$ \\
\hline LPDRBJ & Lag PDRB Jawa timur & \\
\hline
\end{tabular}

Sumber : Data Primer (2018)

\section{Hasil dan Pembahasan}

\section{Keragaan Subsektor Peternakan Sapi di Jawa Timur}

Usaha ternak sapi potong sebagian besar merupakan usaha peternakan rakyat berskala kecil dengan ciri kepemilikan ternak sapi potong yang masih rendah. Jumlah kepemilikan ternak yang masih rendah disebabkan oleh sistem pemeliharaannya yang masih tradisional. Pengelolaan usaha peternakan rakyat menghadapi permasalahan dimana masih terbatasnya kemampuan sumber daya manusia sering menjadi kendala dan berdampak pada produktivitas. Karakteristik peternak merupakan salah satu faktor yang sangat penting. Karakteristik ini 
dibangun berdasarkan unsur-unsur demografis, perilaku, psikografis dan geografis. Tingkat karakteristik peternak dalam penelitian ini terbagi menjadi 5 kategori. Karakteristik peternak sapi potong dilihat dari jumlah ternak, periode penjualan, pakan yang digunakan, fungsi ternak dan tempat penjualan sapi.

\section{Jumlah Kepemilikan Ternak}

Jumlah ternak yang dimiliki oleh peternak berpengaruh terhadap hasil atau keuntungan yang diperoleh peternak, dimana semakin banyak memelihara ternak maka semakin meningkatkan pendapatan usaha ternak. Untuk mengetahui jumlah ternak yang dimiliki responden dapat dilihat pada Tabel 2.

Tabel 2: Jumlah Kepemilikan Ternak

\begin{tabular}{cccc}
\hline No. & Kepemilikan Ternak & Jumlah (orang) & Persentase (\%) \\
\hline 1. & $1-3$ & 17 & 56,67 \\
\hline 2. & $4-6$ & 10 & 33,33 \\
\hline 3. & $>6$ & 3 & 10,00 \\
\hline & Total & $\mathbf{3 0}$ & $\mathbf{1 0 0}$ \\
\hline
\end{tabular}

Sumber : Data Primer (2018)

Pada Tabel 2 berdasarkan jawaban kuisioner responden menunjukan bahwa jumlah ternak 1-3 ekor sebanyak 17 orang (56,67\%), jumlah ternak 4-6 ekor sebanyak 10 orang (33,33\%) dan jumlah ternak $>6$ sebanyak 3 orang $(10,00 \%)$. Hasil penelitian menunjukkan bahwa ternak yang dimiliki oleh peternak sapi potong relatif sedikit hanya berkisar 1-3 ekor, sehingga keuntungan atau pendapatan yang diperoleh peternak dari hasil ternak sapi tergolong kecil. Hal ini dikarenakan peternak tidak menjadikan kepemilikan sapi sebagai sumber pendapatan utama, namun disisi lain banyak peternak yang juga bermata pencaharian sebagai petani atau pedagang sehingga kepemilikan ternak hanya menjadi pekerjaan sampingan. Hal ini sesuai dengan Hermanto (1996) yang menyatakan bahwa kepemilikan ternak berpengaruh positif terhadap pendapatan usaha ternak. Semakin banyak memelihara ternak, semakin meningkatkan pendapatan usaha ternak.

2. Periode Penjualan

Periode penjualan sapi potong merupakan waktu yang digunakan oleh peternak dalam menjual ternaknya. Periode penjualan sapi potong dapat dilihat pada Tabel 3 berikut:

Tabel 3: Pakan yang Digunakan

\begin{tabular}{clcccr}
\hline No. & Pakan & Orang & Ya (\%) & Orang & \multicolumn{2}{c}{ Tidak (\%) } \\
\hline 1. & Pakan Hijauan & 30 & 100,00 & 0 & 0,00 \\
\hline 2. & Limbah sisa pertanian (jerami) & 27 & 90,00 & 3 & 10,00 \\
\hline 3. & Limbah sisa industri pertanian (bekatul, dedak) & 23 & 76,67 & 7 & 23,33 \\
\hline 4. & Pakan Fermentasi & 10 & 33,33 & 20 & 66,67 \\
\hline
\end{tabular}

Sumber : Data Primer (2018)

Pada usaha peternakan rakyat, penentuan periode penjualan sapi lebih banyak ditentukan oleh faktor kondisi perekonomian rumah tangga peternak. Hal tersebut dapat dilihat pada Tabel 3 yang menjelaskan bahwa peternak cenderung lebih banyak menjual ternaknya pada saat ada kebutuhan sebanyak 18 orang $(60,00 \%)$. Hal ini dikarenakan sapi merupakan investasi atau tabungan jangka panjang para peternak, sehingga sapi potong yang peternak pelihara digunakan sebagai tabungan yang akan dijual ketika dibutuhkan. Berbeda ketika peter- 
Hasanah, J., Ayati, D. Cattle Farming 4.0 : Development of Livestock Sector Through E-Agriovest (Digital

P. I, \& Pramana, D. B. S Based Investment) to Accelerate Economic Growth in East Java

nak akan membeli sapi yaitu dengan harga yang lebih mahal, karena peternak membutuhkan hewan ternak untuk kembali dijadikan tabungan atau investasi. Harga tidak selalu mendorong peningkatan penawaran oleh peternak atau dengan kata lain kenaikan harga tidak selalu merangsang peternak untuk menjual sapinya.

3. Pakan yang digunakan

Bahan pakan adalah segala sesuatu yang diberikan kepada ternak yang sebagian atau keseluruhannnya dapat dicerna tetapi tidak mengganggu kesehatan ternak tersebut. Untuk mengetahui pemberian pakan yang digunakan oleh peternak dapat dilihat pada Tabel 4.

Tabel 4: Pakan yang Digunakan

\begin{tabular}{clcccc}
\hline No. & \multicolumn{1}{c}{ Pakan } & Orang & Ya (\%) & Orang & Tidak (\%) \\
\hline 1. & Pakan Hijauan & 30 & 100,00 & 0 & 0,00 \\
\hline 2. & Limbah sisa pertanian (jerami) & 27 & 90,00 & 3 & 10,00 \\
\hline 3. & $\begin{array}{l}\text { Limbah sisa industri pertanian } \\
\text { (bekatul, dedak) }\end{array}$ & 23 & 76,67 & 7 & 23,33 \\
\hline 4. & Pakan Fermentasi & 10 & 33,33 & 20 & 66,67 \\
\hline
\end{tabular}

Sumber : Data Primer (2018)

Berdasarkan Tabel 4 dapat dilihat bahwa keseluruhan peternak menggunakan pakan hijauan $(100,00 \%)$, selain itu hampir semua peternak $(90,00 \%)$ juga menggunakan limbah sisa pertanian seperti jerami. Hal ini dikarenakan semua pakan tersebut banyak tersedia di seluruh daerah peternak yang mayoritas penduduknya berprofesi sebagai petani. Selain itu, pakan-pakan tersebut merupakan pakan utama ternak sapi potong. Dari Tabel 4 dapat dilihat bahwa peternak $(76,67 \%)$ sebagian besar menggunakan pakan tambahan seperti bekatul dan dedak. Hal ini dikarenakan dalam penggunaaan pakan tambahan akan menunjang pertumbuhan maupun perkembangbiakan sapi potong. Sebagian kecil peternak (33,33\%) juga menggunakan pakan fermentasi, namun sebanyak 66,67\% peternak tidak menggunakan pakan fermentasi. Hal ini dikarenakan dalam proses pembuatan pakan fermentasi membutuhkan waktu dan tenaga, sedangkan mayoritas peternak memiliki pekerjaan lain seperti petani maupun pedagang, sehingga hal tersebut akan menyita waktu peternak.

\section{Fungsi Ternak}

Pemeliharaan sapi pada umumnya dilakukan oleh petani di lahan sawah. Hal ini ada kaitannya dengan kebutuhan petani akan ternak sapi dalam sistem usahatani yang mereka lakukan di lahan sawah. Fungsi ternak yang digunakan oleh peternak sapi dapat dilihat pada Tabel 5 berikut.

Tabel 5: Tempat Penjualan Sapi

\begin{tabular}{clcc}
\hline No. & Keterangan & Jumlah (orang) & Persentase (\%) \\
\hline 1. & Blantik & 20 & 66,67 \\
\hline 2. & Pedagang Besar & - & - \\
\hline 3. & Pasar Hewan & 10 & 33,33 \\
\hline & Total & $\mathbf{3 0}$ & $\mathbf{1 0 0}$ \\
\hline
\end{tabular}

Sumber : Data Primer (2018)

Berdasarkan Tabel 5 menunjukkan bahwa fungsi sapi paling dominan digunakan untuk saving atau tabungan (46,66\%). Kondisi ini menunjukkan bahwa peternak memelihara sapi untuk dibesarkan/digemukkan dan pada saat-saat tertentu apabila keluarga membutuhkan uang seperti untuk sekolah anak, perayaan pernikahan, membangun rumah dan keperluan lainnya 
maka sapi akan dijualnya. Fungsi lainnya sebagai penghasil pupuk (26,67\%), dimana mayoritas peternak memiliki pekerjaan lain seperti bertani, sehingga sapi digunakan sebagai sumber pupuk melalui kotoran sapi yang dapat meminimalisir biaya usahatani yang dilakukan. Disamping sebagai saving dan sumber pupuk, sapi juga digunakan sebagai sumber pendapatan dan tenaga kerja. Hal ini dikarenakan peternak yang mengalami gagal panen dapat menambah pendapatan dengan memelihara sapi yang kemudian dijualnya. Selain itu, beberapa peternak juga masih menggunakan sapi sebagai sumber tenaga kerja untuk mengolah lahan pertaniannya.

\section{Tempat Penjualan Sapi}

Pemasaran sapi potong akan menjadi problem yang cukup besar jika peternak tidak mampu memperkirakan atau menaksir bobot badan sapi. Akibat yang langsung dirasakan adalah kerugian yang cukup besar, karena pada umumnya jual beli sapi dilakukan tanpa menggunakan timbangan (Hardiyanto et al., 2002). Untuk mengetahui mengenai tempat penjualan ternak sapi potong para peternak dapat dilihat pada Tabel 6.

Tabel 6: Tempat Penjualan Sapi

\begin{tabular}{clcc}
\hline No. & Keterangan & Jumlah (orang) & Persentase (\%) \\
\hline 1. & Blantik & 20 & 66,67 \\
\hline 2. & Pedagang Besar & - & - \\
\hline 3. & Pasar Hewan & 10 & 33,33 \\
\hline & Total & $\mathbf{3 0}$ & $\mathbf{1 0 0}$ \\
\hline
\end{tabular}

Sumber : Data Primer (2018)

Berdasarkan Tabel 6 dapat dilihat bahwa para peternak lebih banyak menjual sapinya kepada atau melalui blantik sebesar 66,67\%. Hal ini dikarenakan para peternak tidak mengetahui standar harga dipasar. Pada umumnya, perantara/blantik lebih menguasai informasi harga maupun penawaran di pasar sehingga bertindak sebagai "penentu harga". Oleh karena itu, para peternak lebih banyak menjual melalui blantik. Hanya sebagian kecil peternak $(33,33 \%)$ yang menjual sapinya ke pasar hewan.

Pengetahuan terkait dengan karakteristik peternak sapi potong menjadi tantangan serta perlu keseriusan dari berbagai pihak dalam pembangunan subsektor peternakan. Pembangunan subsektor peternakan merupakan bagian dari pembangunan sektor pertanian yang memiliki nilai strategis dalam memenuhi kebutuhan pangan yang terus meningkat akibat bertambahnya jumlah penduduk dan meningkatnya pendapatan. Salah satu komoditas subsektor peternakan yang sangat penting dalam mencukupi kebutuhan gizi masyarakat dalam menyediakan kecukupan protein hewani adalah daging sapi. Program Swasembada Daging Sapi dan Kerbau (SDSK) tahun 2014 merupakan salah satu program pemerintah di subsektor peternakan dalam meningkatkan produksi daging dalam negeri yang tercapai jika $90 \%$ kebutuhan konsumsi daging dapat pasok dari produksi dalam negeri. Adapun beberapa indikator yang dapat digunakan untuk melihat perkembangan sektor peternakan antara lain populasi ternak sapi, produksi daging sapi, permintaan daging sapi, harga daging sapi domestik, harga daging sapi impor, PDRB subsektor peternakan Jawa Timur dan PDRB Jawa Timur. Keragaan subsektor peternakan Jawa Timur dapat dilihat pada Tabel 7 berikut. 
Hasanah, J., Ayati, D. Cattle Farming 4.0 : Development of Livestock Sector Through E-Agriovest (Digital

P. I, \& Pramana, D. B. S Based Investment) to Accelerate Economic Growth in East Java

Tabel 7: Keragaan Subsektor Peternakan Jawa Timur Tahun 2008-2017

\begin{tabular}{ccccccccc}
\hline $\begin{array}{c}\text { Ta- } \\
\text { hun }\end{array}$ & $\begin{array}{c}\text { Papi Potong } \\
\text { (ekor) }\end{array}$ & $\begin{array}{c}\text { Produksi } \\
\text { daging sapi } \\
\text { (kg) }\end{array}$ & $\begin{array}{c}\text { Permintaan } \\
\text { daging sapi } \\
\text { (kg) }\end{array}$ & $\begin{array}{c}\text { Harga } \\
\text { daging } \\
\text { domestik } \\
\text { (Rp/Kg) }\end{array}$ & $\begin{array}{c}\text { Harga } \\
\text { daging } \\
\text { sapi im- } \\
\text { por (Rp/ } \\
\text { Kg) }\end{array}$ & $\begin{array}{c}\text { PDRB Subsek- } \\
\text { tor Peternakan } \\
\text { (000 000 } \\
\text { Rupiah) }\end{array}$ & $\begin{array}{c}\text { PDRB Jawa Timur } \\
\text { (000 000 Rupiah) }\end{array}$ & $\begin{array}{c}\text { Kontribusi } \\
\text { (\%) }\end{array}$ \\
\hline 2008 & 3.384 .902 & 85.173 .000 & 83.224 .607 & 50.871 & 21.338 & 18.489 .261 & 621.391 .674 & 3,07 \\
\hline 2009 & 3.458 .948 & 107.768 .000 & 86.089 .976 & 58.178 & 15.878 & 21.061 .493 & 686.847 .557 & 2,99 \\
\hline 2010 & 3.745 .453 & 109.016 .000 & 90.876 .281 & 66.329 & 19.577 & 23.289 .880 & 778.455 .772 & 2,36 \\
\hline 2011 & 4.727 .298 & 112.447 .000 & 97.799 .379 & 69.641 & 20.634 & 26.497 .296 & 1.120 .577 .200 & 2,42 \\
\hline 2012 & 4.957 .478 & 110.762 .000 & 106.290 .475 & 76.925 & 19.468 & 30.182 .294 & 1.248 .767 .290 & 2,40 \\
\hline 2013 & 3.586 .709 & 100.707 .000 & 88.427 .164 & 90.401 & 21.961 & 33.245 .248 & 1.382 .501 .500 & 2,74 \\
\hline 2014 & 4.125 .333 & 97.908 .000 & 91.274 .518 & 99.332 & 23.546 & 42.253 .960 & 1.539 .794 .700 & 2,74 \\
\hline 2015 & 4.267 .325 & 95.431 .000 & 87.368 .165 & 104.328 & 31.201 & 46.242 .230 & 1.689 .882 .400 & 2,70 \\
\hline 2016 & 4.407 .807 & 97.675 .000 & 90.263 .601 & 113.555 & 29.115 & 50.112 .100 & 1.857 .597 .680 & 2,70 \\
\hline 2017 & 4.545 .780 & 96.917 .000 & 94.263 .840 & 115.779 & 26.568 & 54.461 .300 & 2.019 .199 .660 & 2,70 \\
\hline
\end{tabular}

Sumber : BPS (2018)

Berdasarkan Tabel 7, diketahui bahwa pertumbuhan populasi sapi potong di Jawa Timur periode 2008-2017 mengalami peningkatan dengan rata-rata pertumbuhan 4,31\%/ tahun, lebih tinggi dibandingkan dengan pertumbuhan produksi daging sapi potong sebesar 1,83\%/tahun. Hal ini dikarenakan produksi daging sapi potong masih dihadapkan pada beberapa kendala diantaranya adanya alih fungsi lahan pertanian dan masih diperlukannya upaya kebijakan yang mengarah pada ekstensifikasi ternak potong. Menurut Priyono (2017), jika terjadi peningkatan populasi sapi potong pada tahun sebelumnya di Jawa Timur, akan berdampak pada penurunan produksi daging sapi. Hal ini terjadi akibat adanya pengeluaran ternak hidup untuk dipotong diluar daerah Jawa Timur. Selain itu, Jawa Timur merupakan pemasok terbesar, artinya daerah lain harus mengambil sapi dari Jawa Timur untuk memenuhi kebutuhannya sehingga produksi daging sapi potong terus berkurang.

Tabel 7 juga menunjukkan bahwa rata-rata pertumbuhan produksi daging sapi Jawa Timur sebesar $1,83 \% /$ tahun, sedangkan permintaan daging sapi memiliki rata-rata pertumbuhan 1,69\%/tahun. Hal tersebut menunjukkan bahwa Jawa Timur mengalami surplus dalam produksi daging sapi dan sudah mampu memenuhi kebutuhan daging sapi di setiap kabupaten/kota dan tetap berkontribusi untuk kebutuhan daging nasional. Kelebihan ini dapat digunakan untuk memenuhi permintaan dan kebutuhan penduduk diluar Jawa Timur. Surplus daging sapi di Jawa Timur membuat provinsi ini menjadi daerah penyumbang terbesar kebutuhan daging secara nasional. Indonesia saat ini masih mengalami defisit pasokan daging dan membutuhkan peran serta Jawa Timur sebagai daerah penyangga kebutuhan daging sehingga harus dijaga eksistensinya. Surplus ini sebagian besar karena keberhasilan program kawin suntik atau inseminasi buatan yang telah dijalankan di Jawa Timur sejak tahun 1974. Namun, produksi daging sapi yang sudah surplus masih tidak mampu mengendalikan harga daging yang terus meningkat dikarenakan permintaan terhadap daging sapi masih tergolong tinggi.

Permintaan suatu komoditas dipengaruhi oleh harga produk substitusinya, tingkat pendapatan, jumlah penduduk, dan selera masyarakat. Seiring dengan pertambahan penduduk dan meningkatnya pendapatan masyarakat permintaan terhadap produk peternakan juga meningkat, sehingga harga juga ikut meningkat dikarenakan permintaan dan harga memiliki hubungan positif. Perkembangan harga daging sapi di tingkat konsumen sejak tahun 2008 hingga tahun 2017 cenderung terus meningkat. Fenomena terjadinya lonjakan harga dikarenakan konsumsi daging yang tinggi di hari-hari besar keagamaan dan hari raya nasional, khu- 
susnya setiap menjelang puasa sampai lebaran. Realita di lapangan setelah lebaran harga tidak pernah kembali ke posisi awal dan menetap diharga barunya, dan hal ini berulang dari tahun ke tahun juga di tahun 2017. Sebenarnya pemerintah telah berusaha keras mengendalikan kenaikan harga daging sapi di pasaran dengan melakukan impor daging dari negara produsen seperti India, Australia, Selandia Baru, dan Spanyol namun harga daging sapi masih tetap tinggi karena pangsa pasar antara daging sapi beku hasil impor dan daging segar berbeda. Harga daging domestik yang relatif mahal, sebagai akibat dari inefisiensi usaha peternakan domestik yang ditunjukkan oleh tingginya biaya produksi usaha termasuk inefisiensi dalam jalur tata niaga perdagangan dari daerah sentra produksi (industri hulu) sampai ke konsumen (industri hilir). Kondisi demikian berdampak terhadap terhambatnya perkembangan usaha peternakan domestik, baik usaha yang dilakukan pihak feedloter maupun usaha peternakan rakyat yang sifatnya tradisional. Besaran harga daging impor yang relatif lebih murah juga akan mempengaruhi harga komoditas di pasar domestik sehingga akan berdampak pada penurunan produksi daging sapi dan terhadap perkembangan usaha peternakan sapi potong domestik.

Berdasarkan Tabel 7 diketahui bahwa meningkatnya PDRB subsektor peternakan maupun keseluruhan sektor PDRB Jawa Timur tidak lalu membuat kontribusi yang dihasilkan subsektor peternakan juga selalu meningkat. Terlihat kontribusi yang dihasilkan berfluktuasi dengan kontribusi sebesar 3,07\% merupakan kontribusi terbesar yaitu pada tahun 2008 dan untuk kontribusi terendah pada tahun 2010 yaitu sebesar 2,36\%, sedangkan nilai rata-rata kontribusi subsektor peternakan selama kurun waktu 2008-2017 adalah sebesar 2,68\%. Secara keseluruhan, kontribusinya dapat dikatakan dominan menurun dari tahun 2008-2017. Kontribusi subsektor peternakan di Jawa Timur terutama ternak besar belum sepenuhnya menjamin ketersediaannya secara terus-menerus karena menghadapi kendala dalam sistem pengelolaannya yang umumnya masih sangat tradisional dan dengan pola peternakan rakyat, sehingga memiliki resiko yang tinggi terhadap ketidakterjaminan dalam hal; makanan ternak, keamanan dari pencurian, pengrusakan makanan pangan dan lingkungan penduduk. Hal ini dibuktikan dengan jumlah ketersediaan ternak besar yang berfluktuasi akibat pola peternakan rakyat dan maraknya perdagangan ternak yang ilegal. Namun, disisi lain nilai PDRB subsektor peternakan Jawa Timur dari tahun 2008-2017 cenderung mengalami kenaikan. Hal ini membuktikan bahwa subsektor peternakan masih memiliki potensi yang cukup tinggi untuk dikembangkan yang juga didukung oleh kondisi geografis wilayah yang sesuai bagi pengembangan ternak. Potensi dari subsektor peternakan ini dapat diimplementasikan melalui sistem e-agriovest.

\section{Model Sistem e-agriovest}

Pembentukan model kelembagaan e-agriovest dilakukan sebagai peningkatan produksi daging sapi Jawa Timur sehingga dapat meningkatkan pertumbuhan ekonomi Jawa Timur dianalisis dengan pendekatan sistem yang dijelaskan pada gambar sebagai berikut:

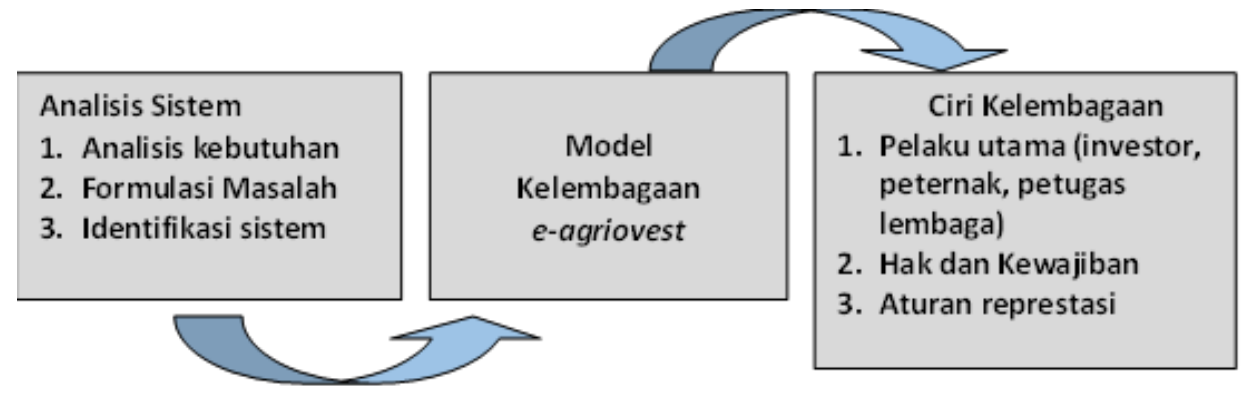

Gambar 3: Analisis Sistem e-agriovest 
Hasanah, J., Ayati, D. Cattle Farming 4.0 : Development of Livestock Sector Through E-Agriovest (Digital

P. I, \& Pramana, D. B. S $\quad$ Based Investment) to Accelerate Economic Growth in East Java

Berdasarkan hasil penelitian mengenai subsektor peternakan Jawa Timur didapatkan kesimpulan bahwa subsektor peternakan masih didominasi oleh peternakan rakyat dengan ciri-ciri sebagai berikut, (a) skala usaha relatif kecil (b) merupakan usaha rumah tangga (c) cara memeliharanya masih tradisional; dan seringkali ternak digunakan sebagai sumber tenaga kerja. Hal ini memberi arti peternak tidak menganggap penting usaha peternakan. Hal tersebut menjadi salah satu penyebab utama produksi daging di Jawa Timur masih relatif rendah. Peternakan rakyat di Jawa Timur banyak dijalankan melalui sistem gaduhan (Simatupang et al., 2016). Sistem gaduhan merupakan suatu usaha bersama antara pemilik modal (investor) yang menyediakan ternak piaraan dan peternak mitra yang nantinya memelihara ternak tersebut. Sistem gaduhan ternak memiliki beberapa kekurangan dimana kemungkinan adanya moral hazard baik di tingkat peternak mitra maupun di tingkat pemodal yang dapat merugikan kedua belah pihak. Sehingga diperlukan strategi guna meningkatkan produksi daging sapi Jawa Timur dengan tetap melibatkan kearifan lokal masyarakat yaitu sistem gaduhan. Tidak cukup sampai disitu strategi peningkatan produksi daging sapi juga harus melibatkan teknologi sesuai dengan revolusi industri 4.0 yang dicanangkan pemerintah.

\section{Formulasi Masalah}

Permasalahan yang dihadapi subsektor peternakan Jawa Timur bersifat teknis maupun nonteknis (kebijakan, manajemen, koordinasi) dimana menghambat dan memperlambat pembangunan peternakan sapi khusunya dai segi produksi daging. Persoalan pertama, masih lemahnya dukungan pembiayaan pengembangan subsektor peternakan baik dari pemerintah maupun perbankan. Para peternak memiliki akses yang rendah terhadap perbankan, baik karena ketidaktahuannya maupun karena kebijakan perbankan yang belum sepenuhnya berpihak kepada peternakan rakyat. Persoalan kedua, manajemen pembangunan peternakan sapi cenderung bersifat alamiah, tanpa terobosan baru, terutama dalam rangka peningkatan populasi yang justru menjadi isu sentral ternak sapi. Persoalan ketiga, tingkat validitas dan reliabilitas data yang lemah. Suatu hal yang seringkali menyulitkan dalam penyusunan perencanaan adalah ketersediaan data yang akurat.

Persoalan keempat, sifat dan karakteristik usaha ternak sapi rakyat yang belum komersial. Berdasarkan hasil pengamatan di beberapa sentra peternakan sapi diperoleh gambaran bahwa ternak sapi hampir seluruhnya diusahakan oleh peternak kecil dengan jumlah yang terbatas. Persoalan kelima, pengembangan ternak sapi membutuhkan lahan yang luas, terutama untuk membangun usaha ternak yang ekonomis dengan skala usaha yang besar. Persoalan keenaam, ketersediaan bibit/bakalan terutama yang bermutu baik atau bibit unggul. Bisnis pembibitan sapi nampaknya tidak menarik bagi investor dengan berbagai pertimbangan. Persoalan keenam adalah lemahnya koordinasi baik antar instansi maupun antara daerah dengan pusat, serta antar pemerintah dan dunia usaha. Masalah klasik yang selalu muncul dan berulang misalnya adalah kewenangan dalam proses impor sapi.

\section{Identifikasi Sistem}

Berdasarkan analisis kebutuhan dan formulasi masalah diperlukan solusi berupa penyusunan model kelembagaan ternak berbasis investasi dan digital di Jawa Timur. e-agriovest merupakan model kelembagaan sebagai fasilitator pengembangan peternakan Jawa Timur guna meningkatkan produksi daging dan akselerasi ekonomi.

\section{Sistem e-agriovest}

Lembaga e-agriovest berada di bawah naungan Dinas Peternakan Provinsi Jawa Timur. Dalam penerapannya Lembaga e-agriovest melibatkan beberapa pihak antara lain, Investor, 
dan Kelompok Peternak (POKNAK). Investor memiliki beberapa kekuatan terhadap modal, kekuatan, teknologi, akses informasi, akses pasar, dan knowledge (Nuhung, 2015). Sementara sebaliknya, peternak mitra memiliki kelemahan pada modal, teknologi, akses informasi, akses pasar, dan knowledge namun memiliki keahlian dalam melakukan kegiatan budidaya ternak sapi. Sistem e-agriovest dijalankan dalam bentuk website untuk menghubungkan investor dan peternak. Investor dapat melakukan investasi dengan kebutuhan dan preferensi masing-masing yang tertera pada website kapan saja (Desain website $e$-agriovest terlampir).

Lembaga e-agriovest diterapkan pada wilayah terpilih di antaranya Sumenep, Tuban, Probolinggo, Jember dan Malang yang merupakan wilayah dengan populasi sapi tertinggi di Jawa Timur. Hal ini dikarenakan selama ini pembangunan subsektor peternakan masih bersifat umum tanpa mempertimbangan wilayah unggul ternak. e-agriovest merupakan e-integrated farming system yang terdiri dari beberapa sektor atau bagian yaitu industri pakan, pembibitan (breeding unit), Budidaya ternak, dan Pemotongan daging (RPH). Lembaga e-agriovest mengintegrasikan beberapa kegiatan dari hulu sampai hilir dalam suatu sistem, sehingga aliran produk sapi dapat dikendalikan secara efektif sesuai dengan kebutuhan dan proses yang berjalan.

Industri pakan sangat dibutuhkan dalam pengembangan subsektor peternakan dimana budidaya sapi di Indonesia hampir semuanya dijalankan dengan sistem setengah intensif dan intensif. Pakan masih menjadi hambatan dan juga sumber biaya yang besar. e-agriovest juga melibatkan industri pakan dalam menyuplai kebutuhan pangan sapi para peternak yang murah dan bernutrisi serta tersedia secara lokal. Unit pembibitan merupakan unit penghasil bakalan, baik untuk dikembangbiakkan maupun untuk bakalan. Hanya dengan cara ini dapat dipastikan adanya jaminan sumber bibit dengan kualitas terjamin, dan tersedia setiap saat tanpa bergantung pada impor sapi bakalan. Sebagai contoh Pemerintah pernah melakukan upaya untuk meningkatkan produktivitas sapi lokal seperti di Sumatera Barat dengan memasukkan bibit sapi dari Eropa misalnya Limousin, Simmental, dan Hereford (Agung et al., 2014).

Unit Budidaya bertugas melakukan kegiatan budidaya ternak sapi. Secara teknis kegiatan budidaya akan dilakukan oleh peternak mitra. e-agriovest perlu melakukan kerja sama dengan kelompok ternak (poknak) dalam memperoleh peternak mitra yang dapat dipercaya dan berpengalaman. Selanjutnya sapi yang telah diternakkan dan siap dipanen dikembalikan pada lembaga e-agriovest untuk dilanjutkan ke unit RPH. e-agriovest melakukan kerjasama dengan Rumah Potong Hewan di daerah masing-masing dan tentunya ada pembagian hasil yang disepakati.

Pemotongan sapi yang dilaporkan merupakan penjumlahan dari sapi impor dan sapi domestik/lokal. Berdasarkan data BPS (2014), menunjukkan bahwa hanya 8,9\% sapi yang dipotong pada RPH, berarti masih cukup besar pemotongan sapi dilakukan di luar RPH atau di Tempat Pemotongan Hewan (TPH) secara tradisional. Seperti diketahui bahwa RPH adalah lembaga resmi untuk pemotongan hewan, sedangkan TPH hanya diizinkan memotong saat hari raya Idul Fitri dan Idul Adha, tetapi kenyataannya berperan seperti RPH dan Pemerintah Daerah memperoleh retribusi dari TPH tersebut. Penerapan sistem e-agriovest menjamin pemotongan hewan hanya dilakukan pada RPH setempat, sehingga produksi daging sapi domestik dapat terdata dengan baik.

Melalui e-agriovest, kapasitas produksi menjadi lebih besar sehingga dapat memenuhi skala ekonomi usaha ternak sapi. Dengan terpenuhinya skala ekonomi maka terjadi efisiensi dan optimasi penggunaan sumber daya, sehingga mendorong peningkatan daya saing produk daging sapi. Terdapat sosial benefit bagi $e$-agriovest dalam bentuk keamanan usaha karena ter- 
Hasanah, J., Ayati, D. Cattle Farming 4.0 : Development of Livestock Sector Through E-Agriovest (Digital

P. I, \& Pramana, D. B. S $\mid$ Based Investment) to Accelerate Economic Growth in East Java

ciptanya rasa memiliki dari kelompok ternak terhadap usaha yang dibangun bersama. Tercipta iklim kondusif dalam pengembangan bisnis, sehingga dapat dijamin keberlanjutan e-agriovest dalam jangka panjang karena adanya nilai tambah baik dalam bentuk ekonomi, sosial dan keamanan bagi e-agriovest, kelompok ternak dan investor. Sehingga, akan mendorong terjadinya kerja sama yang saling menguntungkan dan juga saling ketergantungan yang merupakan perekat yang kuat dalam usaha peternakan sapi potong. Risk sharing merupakan salah satu daya tarik dari e-agriovest yang disepakati oleh e-agriovest, kelompok ternak dan investor di awal kerjasama.

Pengembangan sapi melalui e-agriovest akan menciptakan kesempatan kerja baru bagi masyarakat, sesuai dengan jenis pekerjaan dalam bisnis sapi. Kesempatan kerja tersebut dapat berupa tenaga manajerial, petugas lapangan lembaga, kegiatan pendukung, pemasok sarana produksi dan pakan untuk keperluan bisnis sapi. Dengan demikian, adanya e-agriovest akan mengurangi urbanisasi, karena tersedianya kesempatan kerja di perdesaan. Perekonomian perdesaan akan berkembang sebagai akibat dari kegiatan ekonomi yang dipicu oleh e-agriovest yang memberikan efek ganda terhadap pendapatan, kesempatan kerja, aspek sosial, dan aspek kehidupan lainnya serta dapat mengurangi ketimpangan pendapatan antar kelompok masyarakat dan ketimpangan pembangunan antara desa dengan kota. Secara sistematis model sistem Lembaga e-agriovest digambarkan Gambar 4 berikut.

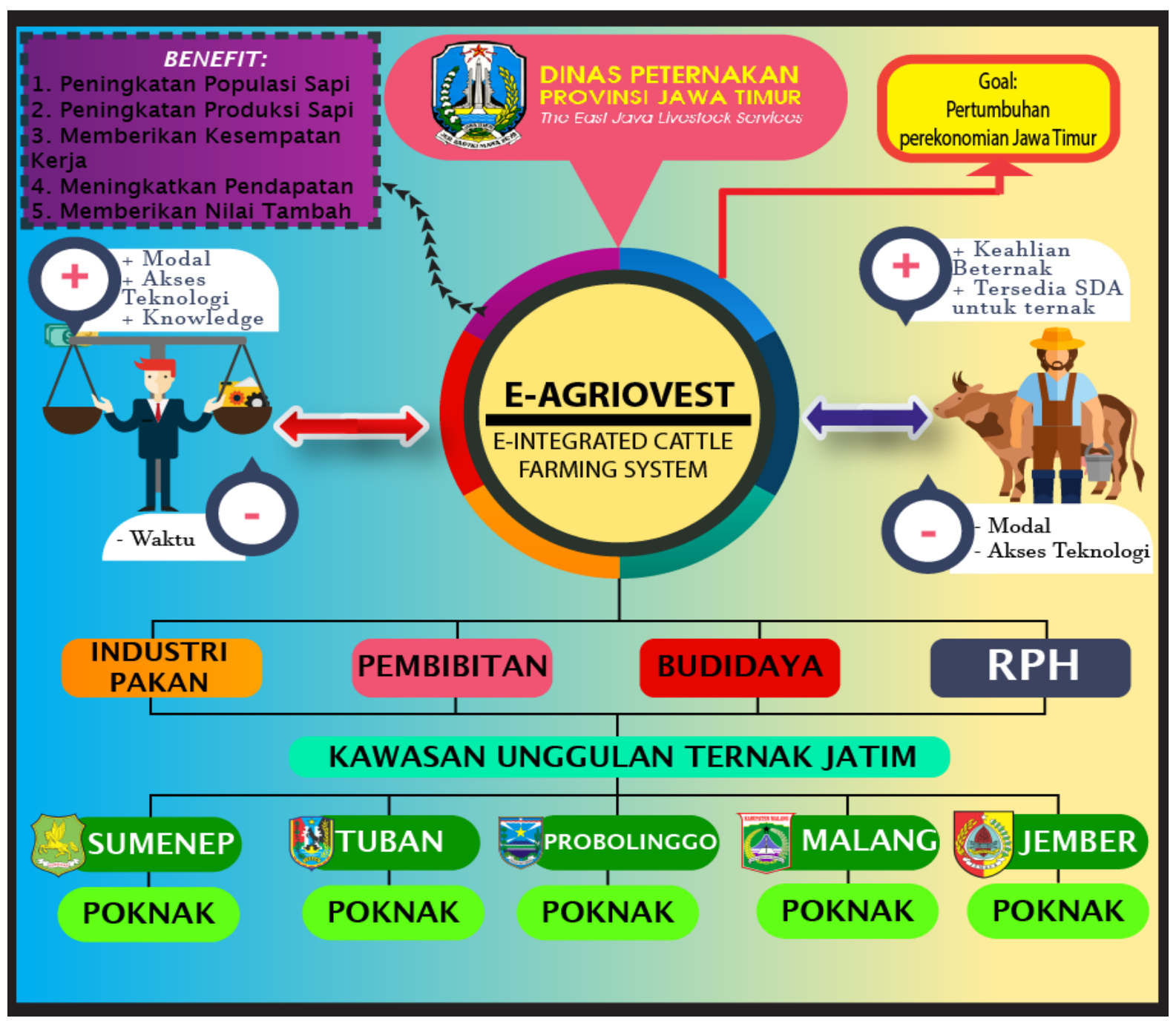

Gambar 4: Pihak-pihak dalam Lembaga e-agriovest 


\section{Sistem Investasi dalam Lembaga e-agriovest}

Sistem investasi harus jelas bagi e-agriovest, kelompok ternak dan investor. Berikut merupakan aturan dasar investasi pada Lembaga e-agriovest.

1. Nominal investasi untuk satu lot (1 ekor sapi terdiri dari 3lot) adalah senilai Rp 3.000.000,- Rp 5.000.000,- tergantung pada jenis sapi yang dirawat dengan jangka waktu investasi selama 4 bulan.

2. Satu ekor sapi terdiri dari 3 lot. Investor bebas menentukan berapapun jumlah lot yang ingin diinvestasikan. Lot yang dipilih akan digabung dengan lot investor lain dengan sistem kolektif.

3. e-agriovest menggunakan sistem kolektif, dimana seluruh sapi yang nantinya dirawat adalah milik bersama seluruh investor, sesuai dengan lot yang diinvestasikan. Tidak ada investor yang memiliki sapi tertentu secara spesifik.

4. Pembagian keuntungan menggunakan sistem bagi hasil (Profit \& Loss Sharing). Dimana pembagian keuntungan antara Investor, Peternak Mitra, dan e-agriovest adalah 45:53:2. Adapun estimasi return adalah 6\%-13\%.

PENTING: bukan fixed-return, akadnya adalah bagi hasil, apapun yang terjadi akan ditanggung bersama oleh e-agriovest, Peternak Mitra dan Investor, baik untung maupun rugi.

5. Masa periode investasi adalah 4 bulan, keuntungan beserta modal awal akan investor terima setelah sapi terjual di bulan ke-4. Lokasi perawatan sapi berlokasi di beberapa kabupaten unggul ternak.

6. Setiap sapi yang dirawat akan diasuransikan. Sehingga apabila terjadi kematian pada sapi tersebut, pihak asuransi akan melakukan penggantian $85 \%$ dari harga beli. Hal ini sebagai mitigasi risiko kematian yang mungkin terjadi di dalam masa perawatan.

7. Simulasi perhitungan keuntungan (1 lot, dengan harga per Lot adalah Rp 3.000.000,-.. - Rp 5.000.000,- 1 ekor sapi terdiri dari 3 lot)

Profit rata-rata 1 sapi $=$ Rp 4.000.000,-

Profit untuk investor $45 \%=\mathrm{Rp} 1.800 .000,-$

Profit 1 lot $=$ Rp 1.800.000,- / 6 lot $=$ Rp 300.000,-

Return Investor $=$ modal awal + profit 1 lot $\backslash$

$$
=\operatorname{Rp} 4.000 .000+\operatorname{Rp} 300.000
$$

$=$ Rp. $4 \cdot 300 \cdot 000$

\section{*catatan :}

a. Jika lebih dari 1 lot, keuntungan yang didapat hanya tinggal dikali dengan keuntungan 1 lot.

b. Angka profit ratprofita-rata 1 sapi di atas adalah estimasi. Bisa lebih atau kurang dari angka tersebut.

\section{Dampak Sistem e-agriovest Terhadap Ekonomi Jawa Timur}

Hasil estimasi Model Produksi Daging Sapi Jawa Timur setelah adanya sistem e-agriovest akan dibahas secara rinci pada setiap persamaan. Model yang digunakan telah mengalami beberapa kali perubahan spesifikasi, dan hasil estimasi parameter telah sesuai dengan kriteria ekonomi, statistik, dan ekonometrik.

Model Produksi Daging Sapi Jawa Timur seperti yang dirumuskan pada bahasan sebelumnya menunjukkan keterkaitan harga daging sapi, populasi daging sapi, dan harga daging sapi impor yang diestimasi menggunakan metode 2SLS (Two-Stage Least Square) berdasarkan 
data time series dari tahun 1997 sampai tahun 2017 yang dikumpulkan dari berbagai sumber. Setelah dilakukan respesifikasi terhadap Model, diperoleh 6 persamaan yang terdiri atas 5 persamaan struktural dan 1 persamaan identitas. Respesifikasi dilakukan untuk memperoleh model yang baik menurut kriteria ekonomi, statistik, dan ekonometrika.

Berdasarkan hasil estimasi parameter, maka model yang digunakan dalam penelitian ini cukup baik dalam menjelaskan perilaku produksi ternak sapi, dan kinerja ekonomi subsektor peternakan Jawa Timur yang dilihat dari kontribusi PDRB. Berikut disajikan hasil estimasi untuk kelima blok yang dianalisis yaitu Blok Produksi Daging Sapi, Blok Populasi Daging Sapi, Blok Permintaan Daging Sapi, Blok Harga Daging Sapi, dan Blok Kinerja Pertumbuhan Ekonomi Subsektor Peternakan Jawa Timur yang dapat dilihat pada Tabel 8.

Tabel 8: Hasil Pendugaan Parameter dan Uji Statistik Periode 1997-2017

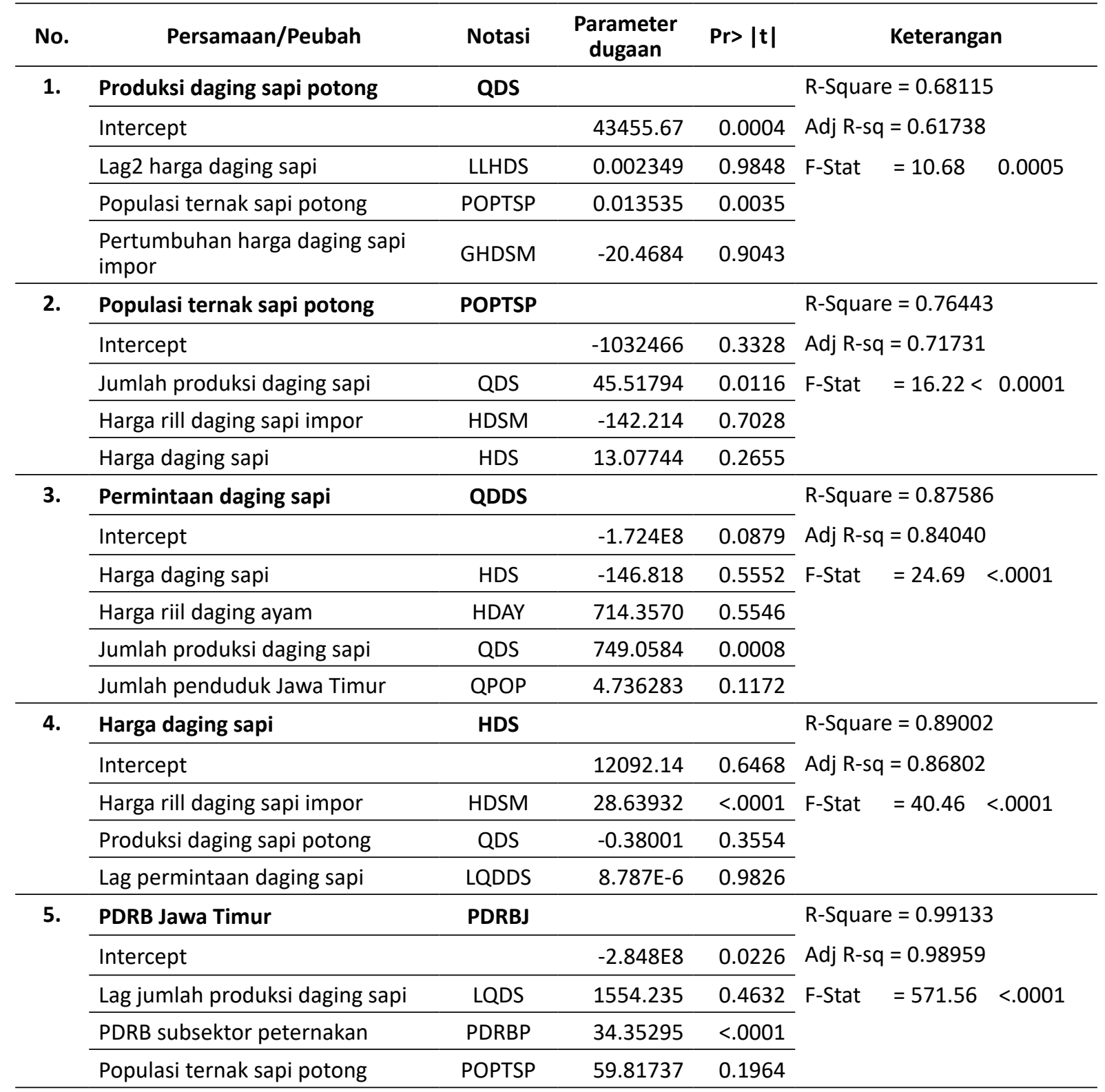

Sumber : Data Primer (2018)

1. Produksi Ternak Sapi Potong

Hasil estimasi parameter produksi ternak sapi potong disajikan pada Tabel 8. Dalam 
penelitian ini produksi ternak sapi potong merupakan gabungan dari seluruh usaha peternakan sapi potong baik yang berasal dari usaha peternakan rakyat maupun perusahaan peternakan. Hasil analisis menunjukkan bahwa variasi peubah-peubah penjelas secara bersama-sama mampu menjelaskan sekitar 68 persen variasi produksi ternak sapi potong di Indonesia, dan sisanya sekitar 32 persen dijelaskan oleh peubah lain yang belum masuk dalam model. Berdasarkan hasil uji statistik-t, produksi daging sapi potong dipengaruhi oleh harga daging sapi dan pertumbuhan harga daging sapi impor pada taraf tidak nyata sementara produksi daging sapi potong dipengaruhi oleh populasi ternak sapi potong pada taraf nyata atau nilai $\alpha$ sebesar 0,013 .

Hasil pendugaan menunjukkan bahwa kenaikan harga daging sapi potong pada tahun t- 2 cenderung meningkatkan produksi ternak sapi, namun tidak berpengaruh nyata pada taraf nyata atau $\alpha$ sebesar 0.98. Menurut Kusriatmi (2015), harga pada tahun sebelumnya merupakan referensi bagi produsen daging sapi untuk merencanakan tingkat produksinya. Seperti halnya produk pertanian pada umumnya, proses produksi daging sapi memerlukan waktu yang relatif lama sehingga respon produksi terhadap perubahan harga tidak bisa dilakukan dalam waktu yang singkat. Menurut Marsh (1994), pada peternakan besar seperti sapi, respon produksi terhadap perubahan harga, teknologi, dan kebijakan pemerintah memerlukan waktu yang relatif panjang karena faktor biologis. Kenaikan harga daging merupakan insentif bagi produsen daging sapi lokal untuk meningkatkan produksinya. Dengan asumsi harga input konstan, kenaikan harga daging akan meningkatkan value of marginal product sehingga produsen akan meningkatkan penggunaan input untuk mendapatkan output yang lebih besar dan memperoleh keuntungan yang lebih tinggi.

Populasi ternak sapi pada juga berpengaruh positif dan nyata secara statistik terhadap produksi daging sapi lokal. Populasi ternak adalah jumlah ternak pada akhir tahun. Dengan masa kebuntingan sekitar 9 bulan, maka ternak sapi yang meengalami proses pembuahan pada tahun t-1 diperkirakan akan melahirkan pedet pada tahun berikutnya. Keberadaan sapi betina induk sangat penting untuk menghasilkan anak sapi. Dalam hal ini, populasi ternak berpengaruh nyata dalam memproduksi ternak sapi bisa disebabkan proses pembuahan yang efektif.

Di sisi lain, pertumbuhan harga impor daging sapi berpengaruh negatif terhadap produksi daging sapi lokal. Dengan harga daging sapi impor yang relatif lebih rendah dibandingkan dengan harga daging sapi domestik, maka daging sapi lokal tidak bisa bersaing dengan daging sapi impor. Dengan demikian, jika terjadi kenaikan harga impor produk daging sapi, maka produksi daging sapi lokal akan menurun karena konsumen yang rasional akan lebih memilih daging sapi impor yang harganya lebih murah apalagi dengan kualitas yang lebih bagus.

\section{Populasi Ternak Sapi Potong}

Populasi ternak sapi adalah jumlah ternak sapi pada tahun tertentu. Hasil pendugaan parameter faktor-faktor yang mempengaruhi populasi ternak sapi disajikan pada Tabel 8 . Nilai koefisien determinasi (R2) sebesar 0.764 yang mengandung arti keragaman peubah-peubah penjelas secara bersama-sama mampu menjelaskan 76.4 persen keragaman populasi ternak sapi. Berdasarkan uji statistik-t menunjukkan bahwa populasi ternak sapi dipengaruhi oleh jumlah produksi ternak sapi pada taraf nyata 1 persen. Sementara populasi ternak sapi juga dipengaruhi oleh harga riil daging sapi impor dan harga daging sapi pada taraf tidak nyata.

Peningkatan produksi ternak yang menunjukkan peningkatan jumlah kelahiran hidup akan menambah populasi ternak. Sedangkan produksi daging yang menggambarkan tingkat 
Hasanah, J., Ayati, D. Cattle Farming 4.0 : Development of Livestock Sector Through E-Agriovest (Digital

P. I, \& Pramana, D. B. S Based Investment) to Accelerate Economic Growth in East Java

pemotongan ternak akan menurunkan populasi ternak. Produksi daging berasal dari pemotongan ternak sapi domestik ditambah dengan pemotongan sapi bakalan impor. Semakin tinggi produksi daging mengindikasikan semakin banyak jumlah ternak sapi yang dipotong dan semakin besar pengurangan populasi ternak. Sebenarnya masih ada faktor lain yang dapat mengurangi populasi ternak, yaitu ekspor ternak dan kematian ternak. Dalam penelitian ini kedua variabel tersebut tidak dimasukkan dalam model dengan pertimbangan volume ekspor ternak sangat kecil dan dalam beberapa tahun tidak ada ekspor ternak sapi sama sekali (volume nol). Sementara variabel tingkat kematian ternak karena keterbatasan data yang tersedia.

Di sisi lain, harga riil daging sapi impor berpengaruh negatif terhadap populasi ternak sapi lokal. Dengan harga daging sapi impor yang relatif lebih rendah dibandingkan dengan harga daging sapi domestik, maka daging sapi lokal tidak bisa bersaing dengan daging sapi impor. Dengan demikian, jika terjadi kenaikan harga impor produk daging sapi, maka produksi daging sapi lokal akan menurun karena konsumen yang rasional akan lebih memilih daging sapi impor yang harganya lebih murah apalagi dengan kualitas yang lebih bagus. Penurunan produksi sapi tentunya akan menurunkan populasi sapi lokal.

Sebaliknya, harga daging sapi domestik pada tahun sebelumnya berpengaruh positif dan nyata secara statistik terhadap populasi sapi lokal. Harga pada tahun sebelumnya merupakan referensi bagi produsen daging sapi untuk merencanakan tingkat produksinya. Seperti halnya produk pertanian pada umumnya, proses produksi daging sapi memerlukan waktu yang relatif lama sehingga Kenaikan harga daging merupakan insentif bagi produsen daging sapi lokal untuk meningkatkan produksinya atau dengan kata lain meniingkatkan jumlah ternak yang dibudidayakan.

\section{Permintaan daging sapi}

Hasil pendugaan parameter faktor-faktor yang mempengaruhi permintaan daging sapi di Jawa Timur pada Tabel 8 menunjukkan Nilai koefisien (R2) sebesar 0.87586 mengandung arti bahwa $87,58 \%$ variasi permintaan daging sapi dapat dijelaskan oleh variasi peubah penjelas secara bersama-sama. Peubah-peubah tersebut adalah harga daging sapi domestik, harga daging ayam ras, produksi daging sapi potong, dan jumlah penduduk. Berdasarkan uji statistik-t menunjukkan bahwa permintaan daging sapi dipengaruhi oleh jumlah produksi ternak sapi pada taraf nyata 1 persen. Sementara permintaan daging sapi juga dipengaruhi oleh harga riil daging sapi, harga riil daging ayam dan jumlah penduduk pada taraf tidak nyata.

Kenaikan harga daging sapi domestik akan mengakibatkan menurunnya permintaan daging sapi. Peubah penjelas harga daging sapi domestik bernilai negatif namun tidak berpengaruh nyata. Hal ini selaras dengan penelitian Handayani et al. (2016) yang menyatakan bahwa bagi masyarakat Indonesia daging sapi masih merupakan barang mewah sehingga tidak responsif terhadap perubahan harga. Harga daging sapi yang tidak responsif, menunjukkan bahwa konsumen daging sapi adalah golongan menengah ke atas yang tidak berpengaruh dengan perubahan harga.

Daging ayam merupakan salah satu komoditas daging sapi dan merupakan salah satu sumber protein hewani bagi masyarakat. Meskipun harga daging ayam tidak berpengaruh nyata terhadap permintaan daging sapi domestik tetapi kenaikan harga daging ayam akan meningkatkan permintaan terhadap daging sapi. Jika harga daging sapi mahal maka konsumen akan beralih mengkonsumsi daging ayam. Hasil penelitian Kusriatmi (2014) menunjukkan bahwa konsumen akan cenderung mengkonsumsi salah satu komoditas daging tersebut berdasarkan pertimbangan harga, jika harga daging sapi mahal maka konsumen akan beralih 
mengkonsumsi daging ayam dan sebaliknya. Harga daging sapi sekitar dua kali lipat harga daging ayam, bahkan beberapa tahun terakhir harganya naik lebih pesat dibandingkan harga daging ayam. Dengan harga daging sapi yang cukup tinggi, maka kenaikan harga daging ayam tidak berpengaruh banyak terhadap kenaikan permintaan daging sapi.

Hasil analisis menunjukkan bahwa peubah penjelas produksi daging sapi bertanda positif dan nyata secara statistik terhadap permintaan daging sapi. Dengan kata lain, permintaan akan daging sapi meningkat seiring dengan meningkatnya produksi daging sapi. Produksi daging sapi yang meningkat tentu akan mempengaruhi konsumsi daging sapi maupun produk turunannya. Hal ini mengindikasikan bahwa permintaan daging sapi juga berasal dari produksi daging sapi Jawa Timur dikarenakan permintaan produk peternakan berkaitan erat dengan daya lebih konsumen. Peningkatan pendapatan per kapita akan meningkatkan daya beli masyarakat akan daging sapi. Selain itu, kesadaran masyarakat akan pemenuhan kebutuhan gizi hewani yang dapat terpenuhi dari mengkonsumsi daging sapi juga tinggi, sehingga jika pendapatannya naik, masyarakat akan meningkatkan pembelian terhadap daging sapi sebagai barang konsumsi dan hal ini akan meningkatkan permintaan terhadap daging sapi.

Populasi penduduk memegang peran yang sangat penting dalam permintaan daging sapi. Hasil analisis menunjukkan bahwa peubah penjelas populasi penduduk bertanda positif namun tidak berpengaruh nyata. Dengan kata lain, permintaan daging sapi domestik tidak responsif terhadap laju peningkatan populasi penduduk. Hal ini dikarenakan, daging sapi potong bukan merupakan bahan makan pokok, oleh karena itu penambahan jumlah penduduk akan menyebabkan penduduk untuk mengurangi permintaan bahan makanan yang bukan merupakan bahan makanan pokok. Selain itu, mengkonsumsi daging sapi adalah kalangan ekonomi menengah ketas dan warga Negara asing, sedangkan masyarakat kalangan menengah ke bawah mengkonsumsi daging sapi pada waktu-waktu tertentu saja misalnya peringatan harihari besar agama atau pelaksanaan pesta adat. Kenyataan ini didukung oleh penelitian sebelumnya yang dilakukan oleh Handayani et al. (2016) yang menyimpulkan bahwa pangan asal ternak, khususnya daging sapi masih merupakan barang mewah bagi masyarakat domestik.

\section{Harga Daging Sapi}

Hasil pendugaan parameter persamaan harga daging sapi domestik menunjukkan nilai koefisien $\mathrm{R}^{2}$ sebesar 0.89002 atau sebesar $89 \%$ keragaman harga daging sapi domestik mampu dijelaskan secara bersama-sama oleh kearagaman harga riil daging sapi impor, produksi daging sapi domestik, dan lag permintaan daging sapi. Berdasarkan hasil uji statistik-t, harga daging sapi potong dipengaruhi oleh produksi daging sapi domestik dan lag permintaan daging sapi pada taraf tidak nyata sementara harga riil daging sapi impor dipengaruhi oleh populasi ternak sapi potong pada taraf nyata.

Harga daging sapi impor berpengaruh positif dan nyata secara statistik terhadap harga daging sapi domestik. Hal tersebut menunjukkan bahwa harga daging sapi impor cenderung meningkatkan harga daging domestik. Bila harga komoditas daging impor meningkat, maka cenderung akan mengurangi volume impor daging sapi. Pengurangan volume impor menyebabkan konsumen daging cenderung beralih untuk mengkonsumsikan daging sapi dalam negeri sehingga akan meningkatkan harga daging domestik. Dalam era perdagangan bebas, perubahan harga dipasar internasional akan berpengaruh terhadap situasi pasar domestik. Indonesia merupakan negara small country, yang berperan sebagai price taker, dimana jika terjadi kenaikan harga daging sapi impor maka harga daging sapi domestik juga mengalami peningkatan. Hasil penelitian Handayani et al. (2016) juga menunjukkan bahwa harga daging impor memberikan pengaruh yang positif. 
Hasanah, J., Ayati, D. Cattle Farming 4.0 : Development of Livestock Sector Through E-Agriovest (Digital

P. I, \& Pramana, D. B. S Based Investment) to Accelerate Economic Growth in East Java

Disisi lain, produksi daging sapi domestik berpengaruh negatif namun tidak nyata terhadap harga daging sapi domestik yang artinya peningkatan jumlah produksi daging sapi akan menurunkan harga, meskipun harga daging sapi tidak responsif terhadap produksi daging sapi. Hal ini dikarenakan jumlah ketersediaan daging sapi di Jawa Timur sudah mampu memenuhi kebutuhan permintaan masyarakat. Selain itu, adanya kendala dalam ketersediaan daging sapi Jawa Timur, dimana ketika persediaan daging sapi berkurang maka produsen akan meningkatkan harga daging sapi yang kemudian akan mengurangi permintaan konsumen terhadap daging sapi dan konsumen akan beralih ke daging ayam yang harganya lebih murah dari daging sapi. Sebaliknya ketika produksi daging sapi meningkat maka harga daging sapi akan menurun. Namun, pada harga daging sapi tipikalnya setelah mengalami kenaikan tidak pernah terjadi penurunan harga kembali ke posisi awal. Oleh karena itu, produksi daging sapi tidak berpengaruh banyak terhadap harga daging sapi.

Sebaliknya, permintaan daging sapi berpengaruh positif terhadap harga daging sapi domestik meskipun tidak berpengaruh nyata. Apabila terjadi kenaikan permintaan daging sapi akibat adanya peningkatan pendapatan atau peningkatan jumlah penduduk, maka akan terjadi excess demand terhadap daging sapi sehingga harga daging sapi dipasar domestik akan meningkat. Adanya kompetitor daging sapi impor dengan harga yang lebih murah, maka perubahan permintaan tersebut bisa saja dipenuhi dari produk impor. Dengan demikian permintaan daging sapi tidak berpengaruh banyak dalam kenaikan harga daging sapi domestik, ditambah jika didukung dengan adanya kemudahan dalam proses impor daging sapi.

\section{PDRB Jawa Timur}

Pertumbuhan ekonomi subsektor peternakan merupakan perubahan nilai Produk Domestik Regional Bruto (PDRB) subsektor peternakan pada tahun berjalan dibandingkan dengan PDRB subsektor peternakan pada tahun sebelumnya. Hasil analisis menunjukkan bahwa keragaman peubah-peubah penjelas secara bersama-sama mampu menjelaskan 99,13\% keragaman PDRB Jawa Timur. potong. Peubah-peubah penjelas tersebut adalah lag produksi daging sapi potong, PDRB subsektor peternakan dan populasi ternak sapi potong. Beradasarkan hasil uji statistik-t, PDRB Jawa Timur dipengaruhi oleh PDRB subsektor peternakan pada taraf nyata. PDRB Jawa Timur juga diperngaruhi lag produksi daging sapi potong dan populasi ternak sapi potong pada taraf tidak nyata.

Lag produksi daging sapi potong berpengaruh positif namun tidak nyata terhadap PDRB Jawa Timur. Hal ini dikarenakan laju peningkatan populasi penduduk dan perbaikan taraf hidup masyarakat Jawa Timur mendorong peningkatan kebutuhan pangan dan konsumsi makanan rumah tangga bertahap mengalami perubahan kearah peningkatan konsumsi protein hewani (daging sapi). Peningkatan laju konsumsi terhadap daging sapi berdampak pada pengurangan produksi sapi potong dalam jangka panjang dan akan terjadi kekurangan produksi akibat adanya pengurasan ternak sapi yang berlebihan, sehingga masih harus disuplai dari impor. Sehingga lag produksi daging sapi tidak berpengaruh banyak dalam peningkatan PDRB Jawa Timur.

Disisi lain, populasi sapi potong juga berpengaruh positif, namun tidak nyata secara statistik. Hal ini dikarenakan perkembangan subsektor peternakan salah satunya dapat dilihat berdasarkan populasi ternak. Namun, saat ini jumlah pemotongan dari jumlah ternak masih tinggi, dimana dalam 1 tahun terjadi 4-5 kali pemotongan, sehingga hal ini akan sangat berpengaruh terhadap ternak potong. Semakin tinggi jumlah pemotongan dari pada jumlah ternak yang ada akan menyebabkan pengurasan stok ternak yang berdampak pada pengurangan populasi. Selain itu, pola pemeliharaan tradisional (peternakan rakyat), tingginya pemotongan 
pejantan yang berdampak pada kekurangan pejantan, pemotongan ternak betina produktif, kekurangan pakan (musim kemarau), kematian pedet yang cukup tinggi masih menjadi penyebab dalam penurunan produksi dan populasi ternak sapi potong. Sehingga, populasi tidak berpengaruh banyak terhadap PDRB Jawa Timur.

Peningkatan PDRB subsektor peternakan akan meningkatkan PDRB Jawa Timur dengan asumsi subsektor yang lain relatif konstan. PDRB subsektor peternakan secara statistik berpengaruh postif dan nyata terhadap PDRB Jawa Timur yang ditunjukkan melalui pertumbuhan subsektor peternakan yang semakin meningkat setiap tahunnya (Tabel 7). Hal ini terjadi dikarenakan tingkat pendapatan perkapita yang mulai meningkat mengakibatkan daya beli masyarakat terhadap produk peternakan semakin tinggi karena kesadaran masyarakat akan pentingnya konsumsi protein hewani yang berasal dari produk-produk peternakan. Peningkatan daya beli masyarakat terhadap produk peternakan turut mendorong permintaan akan produk peternakan. Hal-hal tersebut dapat dijadikan peluang untuk mengembangkan usaha penggemukan sapi dan menjadikan usaha penggemukan sapi sebagai lahan usaha yang prospektif untuk dikelola. Disamping itu, dengan pengembangan usaha ternak, maka diharapkan dapat memenuhi tantangan dalam ketahanan pangan, lapangan pekerjaan, kesejahteraan masyarakat, serta meningkatkan perekonomian baik regional dan nasional. Oleh karena itu, peningkatan subsektor peternakan berpengaruh terhadap peningkatan PDRB Jawa Timur. Dalam hal ini e-agriovest dapat menjadi solusi dalam pengembangan usaha ternak, sehingga dapat meningkatkan nilai PDRB Jawa Timur.

Adanya sistem e-agriovest diramalkan akan meningkatkan produksi daging sapi potong Jawa Timur sebesar $20 \%$. Kenaikan tersebut akan berpengaruh pada ekonomi subsektor peternakan Jawa Timur. Peningkatan kontribusi subsektor peternakan diperkirakan akan meningkatkan nilai PDRB Jawa Timur atau dengan kata lain terdapat akselerasi pertumbuhan ekonomi Jawa Timur. Simulasi model bisa berdampak positif maupun negatif atau tidak berdampak sama sekali terhadap masing-masing variabel. Simulasi peramalan dilakukan pada periode pengamatan 1997-2017. Dalam penelitian ini dilakukan simulasi kenaikan produksi yang terkait dengan adanya sistem e-agriovest dalam upaya untuk mewujudkan akselerasi pertumbuhan ekonomi Jawa Timur. Simulasi adanya e-agriovest adalah kenaikan produksi daging sapi potong sebesar $20 \%$. Hasil simulasi peningkatan produksi daging sapi potong sebesar 20\% disajikan pada Tabel 9.

Tabel 9: Dampak Kenaikan Produksi Daging Sapi (20\%) Terhadap Pertumbuhan Ekonomi Jawa Timur (1997-2017)

\begin{tabular}{|c|c|c|c|c|c|c|}
\hline \multirow{2}{*}{ Variabel } & \multirow{2}{*}{ Keterangan } & \multirow{2}{*}{ Satuan } & \multirow{2}{*}{ Nilai Dasar } & \multirow{2}{*}{$\begin{array}{l}\text { Nilai Simu- } \\
\text { lasi }\end{array}$} & \multicolumn{2}{|c|}{ Perubahan } \\
\hline & & & & & Unit & $\%$ \\
\hline POPTSP & Populasi Ternak Sapi Potong & Ekor & 3462090 & 3761132 & 299042 & 8,64 \\
\hline QDDS & Jumlah Permintaan Daging Sapi & $\mathrm{Kg}$ & 78619819 & 79506122 & 886303 & 1,13 \\
\hline HDS & Harga Daging Sapi & $\mathrm{Rp} / \mathrm{Kg}$ & 60691,9 & 60598,6 & $-93,3$ & $-0,15$ \\
\hline PDRBJ & PDRB Jawa Timur & Rupiah & 828610000 & 852090000 & 23480000 & 2,83 \\
\hline
\end{tabular}

Sumber : Data Primer (2018)

Hasil simulasi peningkatan produksi sebesar $20 \%$ berdampak pada peningkatan populasi ternak sapi potong sebesar $8,64 \%$. Kenaikan produksi daging sapi akan mendorong kenaikan populasi ternak, sehingga meningkatkan permintaan daging sapi untuk dikonsumsi sebesar $1,13 \%$. Disisi lain, peningkatan produksi daging sapi sebesar $20 \%$ akan menjaga ketersediaan daging sapi domestik, sehingga berdampak pada penurunan harga daging sapi se- 
Hasanah, J., Ayati, D. Cattle Farming 4.0 : Development of Livestock Sector Through E-Agriovest (Digital

P. I, \& Pramana, D. B. S Based Investment) to Accelerate Economic Growth in East Java

besar $0,15 \%$. Kenaikan produksi daging sapi sebesar $20 \%$ pada akhirnya juga berdampak pada peningkatan PDRB Jawa Timur sebesar 2,83\%.

Berdasarkan hasil analisis tersebut, adanya sistem e-agriovest mampu meningkatkan produksi daging sapi Jawa Timur, sehingga berdampak positif terhadap PDRB Jawa Timur. Sistem e-agriovest merupakan strategi implementatif yang tepat dalam mengembangkan subsektor peternakan guna mempercepat akselerasi pertumbuhan ekonomi Jawa Timur baik secara ekonomi, sosial, dan lingkungan. Namun, dalam mewujudkan hal tersebut tidak terlepas dari peran dan kerjasama beberapa stakeholders seperti pemerintah, swasta, dan masyarakat untuk perekonomian Jawa Timur yang lebih baik.

\section{Simpulan}

Berdasarkan hasil penelitian, karakteristik usaha ternak yaitu (a) jumlah ternak yang dimiliki peternak 1-3 ekor (56,67 \%), 4-6 ekor (33,33\%) dan ternak >6 (10,00\%), (b) Peternak cenderung lebih banyak menjual ternaknya pada saat ada kebutuhan $(60,00 \%)$, (c) jenis Pakan yang digunakan yaitu pakan hijauan (100,00\%), limbah sisa pertanian (90,00\%), pakan tambahan (76,67\%), dan pakan fermentasi (33,33\%),(d) fungsi sapi paling dominan digunakan untuk saving atau tabungan $(46,66 \%)$ dan penghasil pupuk $(26,67 \%),(e)$ para peternak lebih banyak menjual sapinya kepada atau melalui blantik (66,67\%). Peningkatan PDRB subsektor peternakan Jawa Timur (2008-2017) membuktikan bahwa subsektor peternakan masih memiliki potensi yang cukup tinggi untuk dikembangkan.

e-agriovest merupakan e-integrated farming system yang terdiri dari beberapa sektor atau bagian yaitu industri pakan, pembibitan (breeding unit), budidaya ternak, dan pemotongan daging (RPH). e-agriovest merupakan model kelembagaan sebagai fasilitator pengembangan peternakan Jawa Timur guna meningkatkan produksi daging dan akselerasi ekonomi. Lembaga $e$-agriovest berada di bawah naungan Dinas Peternakan Provinsi Jawa Timur. e-agriovest diterapkan pada Kabupaten/Kota terpilih di antaranya Sumenep, Tuban, Probolinggo, Jember dan Malang yang merupakan wilayah dengan populasi sapi tertinggi di Jawa Timur.

Peningkatan produksi sebesar $20 \%$ diramalkan dapat meningkatkan populasi ternak sapi potong sebesar $8,64 \%$. Peningkatan produksi sapi potong juga akan meningkatkan konsumsi daging sapi sapi sebesar $1,13 \%$. Dampak yang terjadi dari peningkatan produksi sapi potong juga akan menyebabkan penurunan harga daging sapi sebesar $0,15 \%$. Peningkatan PDRB juga menjadi dampak dari peningkatan produksi sapi potong, peningkatan PDRB Jawa Timur yang terjadi sebesar $2,83 \%$. Keberadaan sistem e-agriovest menjadi salah satu langkah implementatif dalam pengembangan sektor peternakan guna mempercepat pertumbuhan ekonomi Jawa Timur secara ekonomi, sosial, dan lingkungan.

\section{Daftar Pustaka}

Agung, P. P., Ridwan, M., Handrie, H., Indriawati, I., Saputra, F., Supraptono, S., \& Erinaldi, E. (2014). Profil morfologi dan pendugaan jarak genetik sapi Simmental hasil persilangan. Jurnal Ilmu Ternak Dan Veteriner, 19(2). https://doi.org/10.14334/jitv.v19i2.1039

Anantanyu, S. (2011). Kelembagaan Petani: Peran dan Strategi Pengembangan Kapasitasnya Sapja Anantanyu Staf Pengajar Program Studi Agribisnis Fakultas Pertanian UNS. Pebruari, 7(2).

Badan Pusat Statistik. (2014). Statistik Indonesia 2014. Jakarta: Badan Pusat Statistik.

Badan Pusat Statistik Jawa Timur. (2017). Provinsi Jawa Timur Dalam Angka 2017. Surabaya : Badan Pusat Statistik Jawa Timur. 
Badan Pusat Statistik Jawa Timur. (2018). Provinsi Jawa Timur Dalam Angka 2018. Surabaya: Badan Pusat Statistik Jawa Timur.

Bank Indonesia. (2018). Kajian Ekonomi dan Keuangan Regional Provinsi Jawa Timur. Surabaya: Bank Indonesia Provinsi Jawa Timur.

Eriyatno. (1999). Ilmu Sistem : Meningkatkan Mutu dan Efektivitas Manajemen. Bogor : IPB Press.

Gulo W. (2004). Metodologi Penelitian. Jakarta: PT. Gramedia Widiasarana Indonesia.

Handayani, S., Fariyanti, A., \& Nurmalina, R. (2016). Swasembada Daging Sapi Analisis Simulasi Ramalan Swasembada Daging Sapi Di Indonesia. Sosiohumaniora, 18(1). https:// doi.org/10.24198/sosiohumaniora.v18i1.9358

Hardiyanto R.,Wahyono D.E., Anom C., Suyamto,Kartono G, \& Soemasono S.R. (2002). Strategi Beternak Sapi Potong. Jakarta.

Hermanto, F. (1996). Ilmu usahatani. Jakarta: Penebar Swadaya.

Hudang K. A. (2016). Perencanaan Pengembangan Subsektor Peternakan Dalam Upaya Peningkatan Perekonomian Di Kabupaten Sumba Timur. Jurnal Riset Ekonomi Dan Manajemen, 16(2). https://doi.org/10.17970/jrem.16.1602012.id

Kuncoro M. (2004). Otonomi dan Pembangunan Daerah: Reformasi, Perencanaan, Strategi dan Peluang. Jakarta: Erlangga.

Kusriatmi. (2014). Dampak Kebijakan Swasembada Daging Sapi Terhadap Kinerja Ekonomi Subsektor Peternakan di Indonesia [Disertasi]. Bogor: Sekolah Pascasarjana Institut Pertanian Bogor.

Lin, J.Y., \& Liu, Z. (2000). Fiscal Decentralization and Economic Growth in China. Economic Development and Cultural Change. 49(1) : 1-21. https://doi.org/10.1086/452488

Marsh, J.M. (1994). Estimating Intertemporal Supply Response in The Fed Beef Market. American Journal of Agricultural Economics 71 (August 1994): 444-453.

Nazir M. (2009). Metode Penelitian. Jakarta: Penerbit Ghalia Indonesia.

Nuhung I A. (2015). Kinerja, Kendala, Dan Strategi Pencapaian Swasembada Daging Sapi. Jurnal Forum Penelitian Agroekonomi. 33(1) : 63-80. https://doi.org/10.21082/fae. v33n1.2015.63-80

Paulson N.D., Katchova, A.L., \& Lence, S.H.(2010). An Empirical Analysis of the Determinants of Marketing Contract Structures for Corn and Soybeans. Journal of Agricultural \& Food Industrial Organization. 8(1) : 53-75. https://doi.org/10.2202/1542-0485.1282

Priyono H. (2017). Dinamika Produksi Daging Sapi di Pulau Jawa melalui Pendekatan Ekonometrik. Prosiding Seminar Nasional Dalam Rangka Seminar Nasional Teknologi Peternakan dan Veteriner, Bogor.

Satya V. (2018). Strategi Indonesia Menghadapi Industri 4.0. Jurnal Info Singkat. 10(9): 19-24.

Simatupang, P., Jamal, E., \& Togatorop, M.H. (2016). Sistem Gaduhan Sapi Tradisional Bali: Faktor Pendorong, Penopang dan Karakteristiknya. Forum Penelitian Agro Ekonomi. 12(2) : 50-55. https://doi.org/10.21082/fae.v12n2.1994.50-55 
Siregar, M., \& Ilham, N. (2016). Upaya Peningkatan Efisiensi Usaha Ternak Ditinjau Dari Aspek Agribisnis Yang Berdaya Saing. Forum Penelitian Agro Ekonomi. 21(1) : 57-66. https:// doi.org/10.21082/fae.v21n1.2003.57-66

Suhariyono, A.K. (2013). Analisis Struktur Perekonomian dan Pertumbuhan Ekonomi Di Provinsi Banten Melalui Pendekatan LQ, Shift share [Skripsi]. Semarang: Universitas Negeri Semarang.

Sutopo H.B. (2006). Metodologi Penelitian kualitatif, Dasar teori dan Terapan dalam Penelitian. Surakarta: UNS Press.

Suwandi. (2015). Desentralisasi Fiskal dan Dampaknya Terhadap Pertumbuhan Ekonomi, Penyerapan Tenaga Kerja, Kemiskinan, dan Kesejahteraan di Kabupaten/Kota Induk Provinsi Papua. Yogyakarta: Deepublish.

Yusdja Y \& Ilham N. (2004). Tinjauan Kebijakan Pengembangan Agribisnis Sapi Potong. Analisis Kebijakan Pertanian. 2(2) : 183-203.

Zainuddin A (2015). Integrasi Pasar dan Respon Penawaran Daging Sapi Di Indonesia. Thesis. Bogor: Program Pascasarjana Institut Pertanian Bogor. 